\title{
Genes associated with common variable immunodeficiency: one diagnosis to rule them all?
}

\author{
Delfien J A Bogaert, ${ }^{1,2,3,4}$ Melissa Dullaers, ${ }^{1,4,5}$ Bart N Lambrecht, ${ }^{4,5}$ \\ Karim Y Vermaelen, ${ }^{1,5,6}$ Elfride De Baere, ${ }^{3}$ Filomeen Haerynck ${ }^{1,2}$
}

${ }^{1}$ Clinical Immunology Research Lab, Department of Pulmonary Medicine, Ghent University Hospital, Ghent, Belgium ${ }^{2}$ Department of Pediatric Immunology and Pulmonology, Centre for Primary Immunodeficiency, Jeffrey Modell Diagnosis and Research Centre, Ghent University Hospital, Ghent, Belgium ${ }^{3}$ Center for Medical Genetics, Ghent University and Ghent University Hospital, Ghent, Belgium

${ }^{4}$ Laboratory of Immunoregulation, VIB Inflammation Research Center, Ghent, Belgium

DDepartment of Internal Medicine, Ghent University, Ghent, Belgium

${ }^{6}$ Tumor Immunology Laboratory, Department of Pulmonary Medicine, Ghent University Hospital, Ghent, Belgium

\section{Correspondence to} Dr Filomeen Haerynck, Princess Elisabeth Children's Hospital, 3K12D, Ghent University Hospital, De Pintelaan 185, Ghent 9000, Belgium; Filomeen.Haerynck@uzgent.be

Received 10 February 2016 Revised 7 May 2016 Accepted 10 May 2016 Published Online First 1 June 2016

\section{CrossMark}

To cite: Bogaert DJA, Dullaers $\mathrm{M}$, Lambrecht BN, et al. J Med Genet 2016:53:575-590

\section{ABSTRACT}

Common variable immunodeficiency (CVID) is a primary antibody deficiency characterised by

hypogammaglobulinaemia, impaired production of specific antibodies after immunisation and increased susceptibility to infections. CVID shows a considerable phenotypical and genetic heterogeneity. In contrast to many other primary immunodeficiencies, monogenic forms count for only $2-10 \%$ of patients with CVID. Genes that have been implicated in monogenic CVID include ICOS, TNFRSF13B (TACI), TNFRSF13C (BAFF-R), TNFSF12 (TWEAK), CD19, CD81, CR2 (CD21), MS4A1 (CD20), TNFRSF7 (CD27), IL21, IL21R, LRBA, CTLA4, PRKCD, PLCG2, NFKB1, NFKB2, PIK3CD, PIK3R1, VAV1, $R A C 2, B L K$, IKZF1 (IKAROS) and IRF2BP2. With the increasing number of disease genes identified in CVID, it has become clear that CVID is an umbrella diagnosis and that many of these genetic defects cause distinct disease entities. Moreover, there is accumulating evidence that at least a subgroup of patients with CVID has a complex rather than a monogenic inheritance. This review aims to discuss current knowledge regarding the molecular genetic basis of CVID with an emphasis on the relationship with the clinical and immunological phenotype.

\section{INTRODUCTION}

Common variable immunodeficiency (CVID) is one of the most prevalent primary immunodeficiencies (PIDs) with an important morbidity and high number of medical encounters. ${ }^{12}$ According to the international consensus statement, CVID is defined by a marked decrease in serum IgG, decreased IgM and/or IgA, poor antibody responses to vaccines, and exclusion of defined causes of hypogammaglobulinaemia. ${ }^{2}$ Its prevalence is estimated between $1 / 10000$ and $1 / 50000$ in Caucasians; it is rarely described in Asian and African populations. ${ }^{2}{ }^{3}$ Age of onset is variable, with a peak incidence in childhood and in the second and third decades of life. $^{2}{ }^{3}$ Although patients with CVID share many clinical and immunological features, the degree and severity of the presenting phenotype varies considerably between affected individuals. ${ }^{2}$ The most consistent clinical feature is increased susceptibility to (respiratory tract) infections. Patients may also develop complications related to disrupted immune homoeostasis such as autoimmunity. ${ }^{2}$ Besides impaired Ig production by B cells, abnormalities in almost all components of the immune system have been described in CVID. ${ }^{2}$

The majority of CVID cases occur sporadically. ${ }^{2}$ About $5-25 \%$ of patients have a positive family history, of which most demonstrate an autosomal dominant inheritance. ${ }^{2}$ So far, a monogenic cause has been identified in 2-10\% of patients with CVID. $^{2}{ }^{4}$ The majority of these genetic subtypes are very rare (figure 1 and table 1 ). The first CVID disease genes were discovered using a candidate gene approach based on single-gene knockout mice. $^{5-8}$ This might explain why many genetic defects described thus far are autosomal recessive. The past 4 years, next-generation sequencing (NGS) technologies have accelerated the discovery of both autosomal recessive and dominant CVID disease genes. In addition, it has become clear that the clinical diagnosis of CVID is an umbrella covering several genetic subtypes. In fact, many genes initially reported as CVID disease genes are now considered to be responsible for distinct disease entities (table 1). Moreover, it has been recently suggested that, apart from rare monogenic forms, CVID is a complex rather than a Mendelian disease. $^{2} 49$

This review outlines current knowledge on the molecular basis of CVID, covering both monogenic and complex forms, and linking with clinical and immunological phenotypes.

\section{GENES ASSOCIATED WITH MONOGENIC FORMS OF CVID}

Genes encoding receptors and ligands

ICOS deficiency

Inducible $\mathrm{T}$ cell costimulator (ICOS) is a $\mathrm{T}$ cell surface receptor that belongs to the CD28/CTLA-4 (cytotoxic $\mathrm{T}$ lymphocyte-associated antigen 4) family (figure 2). ${ }^{5}$ Reciprocal ICOS-ICOS ligand interactions are essential for germinal centre (GC) formation and terminal B cell differentiation, effector T cell responses and immune tolerance. ${ }^{5}$

ICOS was the first disease gene identified for monogenic forms of CVID, using a candidate gene approach based on prior evidence from single-gene knockout mice. ${ }^{5}$ Hitherto, biallelic ICOS mutations resulting in complete loss of protein expression have been reported in seven families. ${ }^{5}$ 10-13 Haplotype analysis in the four German/Austrian families segregating an identical ICOS mutation was indicative for a common founder. ${ }^{10} 14$

ICOS-deficient patients had a variable phenotype with variable age of onset and severity (table 1). ${ }^{5}$ 10-13 Patients commonly presented recurrent respiratory tract infections and autoimmune complications. ${ }^{5}{ }^{10-13}$ Patients with two novel ICOS mutations published in 2015 extended the clinical spectrum: early onset inflammatory bowel disease, hepatomegaly with raised liver enzymes, cytomegalovirus viraemia and Pneumocystis jirovecii pneumonia. ${ }^{12}{ }^{13}$ Enteropathy in one ICOS-deficient 


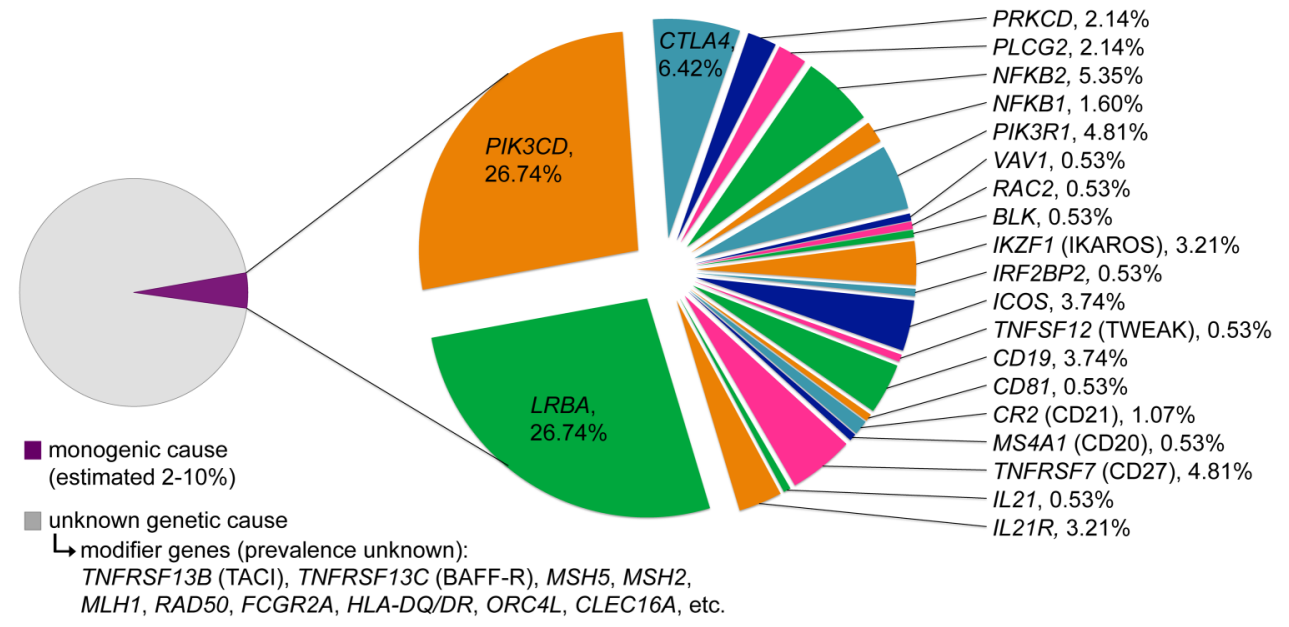

Figure 1 Estimated share of each disease gene within the common variable immunodeficiency population based on published cases.

patient resolved after haematopoietic stem cell transplantation while diarrhoea persisted in his non-transplanted sister. This indicates that inflammatory gut complications are disease-intrinsic. ${ }^{12}$ Noteworthy, decreased ICOS expression was previously reported in an adult Caucasian man with Crohn's-like colitis and panhypogammaglobulinaemia. ${ }^{15}$ Unfortunately, no mutation analysis of ICOS was performed. ${ }^{15}$

All ICOS-deficient patients had very low to absent memory B cells and some also showed a loss of bone marrow plasma cells. ${ }^{5}{ }^{10-14}$ This might be due to defective GC reactions in the absence of ICOS signalling. ${ }^{14}$ ICOS-deficient patients also demonstrated varying degrees of $\mathrm{T}$ cell defects (table 1). In contrast to the first-reported German/Austrian families, the Japanese, Kuwaiti and Pakistani sibling pairs demonstrated pronounced $\mathrm{T}$ cell defects with viral and opportunistic infections resembling combined immunodeficiency (CID) rather than CVID. ${ }^{5}{ }^{10-14}$ Therefore, ICOS mutations are no longer considered to cause a pure CVID phenotype but result in a separate disease entity (ICOS deficiency). ${ }^{12} 13$

\section{TACl and BAFF-R}

Transmembrane activator and calcium modulator and cyclophilin ligand interactor (TACI, encoded by TNFRSF13B), B cell activating factor belonging to the tumour necrosis factor (TNF) family (BAFF)-receptor (BAFF-R, encoded by TNFRSF13C) and $B$ cell maturation antigen (BCMA) are members of the TNF receptor superfamily (TNFRSF) important in peripheral B cell homoeostasis. ${ }^{16}$ These receptors engage two ligands: BAFF and a proliferation inducing ligand (APRIL) (figure 2). Both ligand and receptor oligomerisation are necessary for optimal downstream signalling. ${ }^{16}$ The TACI/BAFF-R/BCMA/BAFF/APRIL system signals through many pathways, ${ }^{16}{ }^{17}$ of which a selection is depicted in figure 2. How the TACI/BAFF-R/BCMA/BAFF/ APRIL system fine-tunes B cell homoeostasis and the degree of mutual redundancy remain incompletely understood. ${ }^{16}{ }^{17}$ TACI mediates IgA and IgG class switch recombination (CSR), differentiation and survival of plasma cells, and T-independent responses to polysaccharide antigens. TACI also acts as an immunoregulator involved in central B cell tolerance and inhibiting peripheral B cell expansion. ${ }^{16}{ }^{17}$ BAFF-BAFF-R signalling promotes peripheral $\mathrm{B}$ cell survival and maturation in synergy with $B$ cell receptor (BCR) signalling. ${ }^{16}$ BCMA plays a role in long-term plasma cell survival in bone marrow. ${ }^{16}$
Variants in the genes encoding TACI and BAFF-R have been identified in patients with CVID by means of a candidate gene approach based on single-gene knockout mice. ${ }^{6-8}$ Although initially thought to be fully penetrant, it is currently believed that monoallelic TNFRSF13B and monoallelic and biallelic TNFRSF13C variants are by themselves not sufficient to cause a CVID phenotype. ${ }^{18-22}$

\section{TNFRSF13B (encoding TACI) variants}

Biallelic and monoallelic loss-of-function variants in TNFRSF13B have been registered in at least 2147 patients based on the Jeffrey Modell Centers Global Network report. ${ }^{1}$ Biallelic TNFRSF13B variants have always been associated with some degree of antibody deficiency, ${ }^{6} 7192023-27$ except for a homozygous C104R variant in a 25 -year-old member of a CVID-affected family who was asymptomatic and had normal Ig levels at the time of the study. ${ }^{24}$ The latter individual could still have developed antibody deficiency later in life, however. ${ }^{24}$ In contrast, monoallelic TNFRSF13B variants have also been detected in asymptomatic relatives and in $1-2 \%$ of the general population. ${ }^{18-21} 2427$

A large variety of variants, mostly missense and nonsense variants, located in all domains of the TACI protein have been reported. ${ }^{6}{ }^{7}$ 18-21 $23-29$ The monoallelic missense variants C104R and A181E account for 80\% of all TNFRSF13B variants in patients with CVID. ${ }^{6}{ }^{18-21}{ }^{23-29}$ In our cohort, we identified the C104R variant in a mother and daughter with CVID (unpublished data). The majority of TNFRSF13B variants do not or only slightly reduce TACI protein expression. ${ }^{29}$ In particular, C104R interferes with ligand binding and A181E affects receptor oligomerisation..$^{29}$ Some patients with CVID have variants located in a highly conserved cytoplasmic domain of TACI (eg, S231R). ${ }^{28}$ In these patients, recruitment of MyD88 to the cytoplasmic TACI domain was disrupted, causing impaired CSR and IgG production (figure 2). ${ }^{28}$ Rarely, patients with CVID with truncating TNFRSF13B variants have been reported. ${ }^{26}$

Patients with CVID with monoallelic or biallelic TNFRSF13B variants can present with a variable phenotype encompassing the complete CVID clinical spectrum (table 1). ${ }^{6}{ }^{18-21}$ In some CVID-affected families, the same TNFRSF13B genotype has also been found in relatives with selective IgA deficiency (sIgAD) or IgG subclass deficiency. ${ }^{6} 72027$ Asymptomatic relatives carrying monoallelic TNFRSF13B variants have been shown to have in vitro functional $\mathrm{B}$ cell defects. ${ }^{21}$ 
Table 1 Genes associated with monogenic forms of CVID: summary of genetic, clinical and immunological features

\begin{tabular}{|c|c|c|c|c|c|c|c|c|}
\hline $\begin{array}{l}\text { Gene, OMIM } \\
\text { number }\end{array}$ & $\begin{array}{l}\text { Number of } \\
\text { publ. } \\
\text { patients }\end{array}$ & Effect on protein & Inheritance & Onset & Clinical spectrum & Immunological spectrum & $\begin{array}{l}\text { CVID or separate } \\
\text { entity }\end{array}$ & Ref \\
\hline \multicolumn{9}{|c|}{ Genes encoding receptors and ligands } \\
\hline $\begin{array}{l}\text { ICOS } \\
{ }^{*} 604558\end{array}$ & 15 (7 fam.) & LOF (absent expr.) & AR & $\begin{array}{l}\text { Infancy to } \\
\text { adulthood }\end{array}$ & $\begin{array}{l}\text { RTI, GI infections, opportunistic infections, bacterial } \\
\text { skin infections, localised herpes simplex infections, } \\
\text { neuroborreliosis, bronchiectasis, AI (incl. Al cytopenia, } \\
\text { rheumatic disease, IBD), BLH, splenomegaly, } \\
\text { hepatomegaly, granulomata, malignancy. }\end{array}$ & $\begin{array}{l}\downarrow \operatorname{lgG}, \downarrow \text { or } \mathrm{nl} \operatorname{lgM}, \downarrow \text { or } \mathrm{nl} \text { IgA, } \downarrow \text { antibody } \\
\text { responses to protein and/or polysaccharide vaccines, } \\
\downarrow \text { or } \mathrm{nl} \text { total B cells, } \downarrow \downarrow \text { or absent memory B cells, } \\
\text { absent bone marrow plasma cells, nl total/CD4 }{ }^{+} / \\
\mathrm{CD}^{+} \mathrm{T} \text { cells, } \downarrow \text { or } \mathrm{nl} \text { CD4 }{ }^{+} \text {and CD8 } 8^{+} \text {memory T } \\
\text { cells, } \mathrm{nl} \text { Treg cells, } \downarrow \text { or } \mathrm{nl} \text { circulating Tfh cells, } \downarrow \text { or } \\
\mathrm{nl} \text { production of Th1/Th2/Th17 cytokines, } \downarrow \text { CTLA-4 } \\
\text { expr, nl CD40(L) expr. }\end{array}$ & ICOS deficiency & 5 10-14 \\
\hline $\begin{array}{l}\text { TNFRSF13B } \\
\text { (TACI), } \\
\text { *604907 }\end{array}$ & 2147 & $\begin{array}{l}\text { LOF (usually nl } \\
\text { expr.) }\end{array}$ & $\begin{array}{l}\text { Monoallelic/ } \\
\text { biallelic }\end{array}$ & $\begin{array}{l}\text { Early } \\
\text { childhood to } \\
\text { adulthood }\end{array}$ & $\begin{array}{l}\text { RTI, GI infections, bronchiectasis, Al (incl. Al } \\
\text { cytopenia, rheumatic disease, IBD), BLH, } \\
\text { splenomegaly ( } \pm \text { splenectomy), granulomata, } \\
\text { malignancy. } \\
\text { Note: variants also found in asymptomatic individuals } \\
\text { and in patients with slgAD or IgG subclass deficiency. }\end{array}$ & $\begin{array}{l}\downarrow \operatorname{lgG}, \downarrow \text { or } \mathrm{nl} \operatorname{lgM}, \downarrow \text { or } \mathrm{nl} \operatorname{lgA}, \downarrow \text { antibody } \\
\text { responses to polysaccharide vaccines, } \downarrow \text { or } \mathrm{nl} \text { or } \uparrow \\
\text { total B cells, } \downarrow \text { or } \mathrm{nl} \text { memory B cells, } \downarrow \text { or } \mathrm{nl} \text { total/ } \\
\mathrm{CD4}^{+} / \mathrm{CD}^{+} \mathrm{T} \text { cells, } \downarrow \text { or } \mathrm{nl} \mathrm{CD} 4^{+} \text {and CD8 } 8^{+} \text {naive/ } \\
\text { memory T cells, } \downarrow \text { or } \mathrm{nl} \text { Treg cells. }\end{array}$ & $\begin{array}{l}\text { CVID, } \\
\text { disease-predisposing }\end{array}$ & $\begin{array}{l}6718-21 \\
23-30\end{array}$ \\
\hline $\begin{array}{l}\text { TNFRSF13C } \\
\text { (BAFF-R), } \\
{ }^{*} 606269\end{array}$ & $>80$ & $\begin{array}{l}\text { LOF/GOF (usually } \\
\text { nl expr.) }\end{array}$ & $\begin{array}{l}\text { Monoallelicl } \\
\text { biallelic }\end{array}$ & $\begin{array}{l}\text { Infancy to late } \\
\text { adulthood }\end{array}$ & $\begin{array}{l}\text { RTI, GI infections, cholangitis, sacroiliitis, } \\
\text { bronchiectasis, AI (incl. Al cytopenia, IBD), BLH, } \\
\text { splenomegaly, granulomata, chronic diarrhoea with } \\
\text { weight loss, failure to thrive. } \\
\text { Note: variants also found in asymptomatic individuals } \\
\text { and in patients with sIgAD or isolated IgM deficiency. }\end{array}$ & $\begin{array}{l}\downarrow \mathrm{lgG}, \mathrm{nl} \text { to undetectable } \mathrm{IgM}, \mathrm{nl} \text { to undetectable } \\
\text { lgA, } \downarrow \text { antibody responses to polysaccharide } \\
\text { vaccines, nl to absent total B cells, nl or } \uparrow \\
\text { transitional B cells, nl or } \downarrow \text { memory B cells, nl total } \\
\text { T cells, nl T cell subsets. }\end{array}$ & $\begin{array}{l}\text { CVID, } \\
\text { disease-predisposing }\end{array}$ & $\begin{array}{l}82225 \\
31-35 t\end{array}$ \\
\hline $\begin{array}{l}\text { TNFSF12 } \\
\text { (TWEAK), } \\
{ }^{* 602695}\end{array}$ & 3 (1 fam.) & LOF (nl expr.) & $A D$ & Infancy & $\begin{array}{l}\text { RTI, pneumococcal meningitis, osteomyelitis, Al } \\
\text { thrombocytopenia and neutropenia, warts. }\end{array}$ & $\begin{array}{l}\downarrow \operatorname{lgG} \text { or low } \mathrm{nl} \text { lgG with } \downarrow \downarrow \lg G 2, \downarrow \operatorname{lgM}, \downarrow \lg A, \downarrow \\
\text { antibody responses to protein and polysaccharide } \\
\text { vaccines, } \downarrow \text { or } \mathrm{nl} \text { total B cells, } \downarrow \text { memory B cells, } \uparrow \\
\text { naive B cells, nl or } \uparrow \text { total T cells, nl total CD4 } 4^{+} T \\
\text { cells, } \uparrow \text { total CD8 }{ }^{+} \mathrm{T} \text { cells, } \uparrow \text { double negative } \mathrm{T} \\
\text { cells, } \downarrow \downarrow \text { in vitro apoptotic function. }\end{array}$ & CVID & 37 \\
\hline $\begin{array}{l}\text { CD19, } \\
* 107265\end{array}$ & 10 (7 fam.) & $\begin{array}{l}\text { LOF }(\downarrow \text { or absent } \\
\text { expr.) }\end{array}$ & AR & $\begin{array}{l}\text { Infancy to } \\
\text { early } \\
\text { childhood }\end{array}$ & $\begin{array}{l}\text { RTI, GI infections, bacterial conjunctivitis ( } \pm \\
\text { dacryocystitis), bacterial skin infections, bronchiectasis, } \\
\text { intermittent microscopic haematuria, postinfectious } \\
\text { glomerulonephritis, IgA nephropathy. }\end{array}$ & $\begin{array}{l}\downarrow \operatorname{lgG}, \downarrow \text { or } \mathrm{nl} \operatorname{lgM}, \downarrow \text { or } \mathrm{nl} \operatorname{lgA}, \downarrow \text { antibody } \\
\text { responses to protein and polysaccharide vaccines, } \mathrm{nl} \\
\text { total CD20 } \mathrm{C} \text { cells, } \downarrow \downarrow \text { memory B cells, } \downarrow \downarrow \mathrm{BCR} \\
\text { signalling, } \mathrm{nl} \text { CD81 expr., } \downarrow \text { CD21 expr., nl total T } \\
\text { cells, } \mathrm{nl} \mathrm{T} \text { cell subsets. }\end{array}$ & CVID & $3841-46$ \\
\hline $\begin{array}{l}C D 81 \\
* 186845\end{array}$ & 1 & LOF (absent expr.) & AR & Infancy & $\begin{array}{l}\text { RTI, Al thrombocytopenia, severe glomerulonephritis } \\
\text { with progression to end-stage renal disease, } \\
\text { undefined systemic inflammatory syndrome. }\end{array}$ & $\begin{array}{l}\downarrow \operatorname{lgG}, \mathrm{nl} \operatorname{lgM}, \downarrow \text { to low } \mathrm{nl} \lg \mathrm{A}, \downarrow \text { antibody } \\
\text { responses to protein and polysaccharide vaccines, } \mathrm{nl} \\
\text { total CD20 B cells, } \downarrow \downarrow \text { memory B cells, } \downarrow \downarrow \mathrm{BCR} \\
\text { signalling, absent CD19 expr., } \downarrow \text { CD21 expr., } \mathrm{nl} \\
\text { total T cells, nl T cell subsets. }\end{array}$ & CVID & 39 \\
\hline $\begin{array}{l}C R 2(C D 21), \\
* 120650\end{array}$ & 2 (2 fam.) & LOF (absent expr.) & $A R$ & $\begin{array}{l}\text { Early } \\
\text { childhood to } \\
\text { childhood }\end{array}$ & $\begin{array}{l}\text { RTI, chronic diarrhoea with weight loss, splenomegaly, } \\
\text { myalgia, rigidity. }\end{array}$ & $\begin{array}{l}\downarrow \operatorname{lgG}, \downarrow \text { or } \mathrm{nl} \operatorname{lgM}, \downarrow \operatorname{lgA}, \downarrow \text { antibody response to } \\
\text { polysaccharide vaccines, nl total CD19+ B cells, } \downarrow \\
\text { memory B cells, mildly } \downarrow \text { BCR signalling, nl CD19/ } \\
\text { CD81 expr., nl total T cells, nl T cell subsets. }\end{array}$ & CVID & 4049 \\
\hline $\begin{array}{l}\text { MS4A1 } \\
(\mathrm{CD} 20) \\
{ }^{*} 112210\end{array}$ & 1 & LOF (absent expr.) & AR & Infancy & RTI & $\begin{array}{l}\downarrow \operatorname{lgG}, \mathrm{nl} \operatorname{lgM}, \mathrm{nl} \operatorname{lgA}, \downarrow \text { antibody responses to } \\
\text { polysaccharide vaccines, nl total B cells, } \downarrow \downarrow \text { memory } \\
\text { B cells, nl total T cells, nl T cell subsets. }\end{array}$ & CVID & 50 \\
\hline $\begin{array}{l}\text { TNFRSF7 } \\
\text { (CD27), } \\
\text { *186711 }\end{array}$ & 17 (9 fam.) & $\begin{array}{l}\text { LOF ( } \downarrow \text { or absent } \\
\text { expr.) }\end{array}$ & AR & $\begin{array}{l}\text { Infancy to } \\
\text { childhood }\end{array}$ & $\begin{array}{l}\text { Chronic EBV viraemia, severe/atypical EBV-associated } \\
\text { infections (eg, severe mononucleosis, pneumonia, } \\
\text { meningitis/encephalitis, oral/perianal ulcers, uveitis), }\end{array}$ & $\begin{array}{l}\downarrow \text { or } \mathrm{nl} \text { or } \uparrow \operatorname{lgG}, \downarrow \text { or } \mathrm{nl} \operatorname{lgM}, \downarrow \text { or } \mathrm{nl} \lg \mathrm{A}, \downarrow \text { or } \mathrm{nl} \\
\text { antibody responses to protein and/or polysaccharide } \\
\text { vaccines, } \downarrow \text { or } \mathrm{nl} \text { total B cells, absent memory B }\end{array}$ & CD27 deficiency & $51-53$ \\
\hline
\end{tabular}




\begin{tabular}{|c|c|c|c|c|c|c|c|c|}
\hline $\begin{array}{l}\text { Gene, OMIM } \\
\text { number }\end{array}$ & $\begin{array}{l}\text { Number of } \\
\text { publ. } \\
\text { patients }\end{array}$ & Effect on protein & Inheritance & Onset & Clinical spectrum & Immunological spectrum & $\begin{array}{l}\text { CVID or separate } \\
\text { entity }\end{array}$ & Ref \\
\hline & & & & & $\begin{array}{l}\text { EBV-induced lymphoproliferation (eg, BLH, } \\
\text { splenomegaly, hepatomegaly, lymphocytic infiltration } \\
\text { of non-lymphoid organs, HLH, lymphoma), RTI, } \\
\text { bronchiectasis, bacterial skin infections, giardiasis, } \\
\text { fulminant bacterial sepsis. }\end{array}$ & 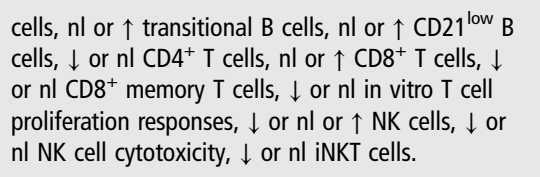 & & \\
\hline IL21, *605384 & 1 & LOF (nl expr.) & AR & Infancy & $\begin{array}{l}\text { RTI, early onset IBD, failure to thrive, recurrent oral } \\
\text { aphthous ulcers. }\end{array}$ & $\begin{array}{l}\downarrow \operatorname{lgG}, \mathrm{nl} \operatorname{lgM}, \mathrm{nl} \lg \mathrm{A}, \uparrow \lg \mathrm{E}, \downarrow \text { antibody responses } \\
\text { to protein and polysaccharide vaccines, } \downarrow \text { total B } \\
\text { cells, } \downarrow \downarrow \text { memory B cells, } \downarrow \text { naive } \mathrm{B} \text { cells, } \uparrow \\
\text { transitional } \mathrm{B} \text { cells, } \mathrm{nl} \text { total/CDD4 } / \mathrm{CD} 8^{+} \mathrm{T} \text { cells, } \downarrow \text { in } \\
\text { vitro } \mathrm{T} \text { cell proliferation responses. }\end{array}$ & IL-21 deficiency & 55 \\
\hline $\begin{array}{l}\text { IL21R, } \\
{ }^{*} 605383\end{array}$ & 8 (6 fam.) & $\begin{array}{l}\text { LOF }(\downarrow \text { or absent } \\
\text { expr.) }\end{array}$ & AR & $\begin{array}{l}\text { Infancy to } \\
\text { early } \\
\text { childhood }\end{array}$ & $\begin{array}{l}\text { RTI, GI infections, opportunistic infections (including } \\
\text { cryptosporidiosis with progression to end-stage biliary/ } \\
\text { liver disease), pulmonary tuberculosis, bronchiectasis, } \\
\text { BLH, hepatosplenomegaly, discoid lupus/chronic } \\
\text { inflammatory skin disease, failure to thrive. }\end{array}$ & 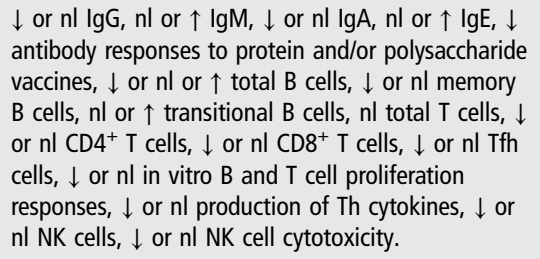 & IL-21R deficiency & $5456-58$ \\
\hline $\begin{array}{l}\text { LRBA, } \\
{ }^{*} 606453\end{array}$ & $>50$ & $\begin{array}{l}\text { LOF (majority } \downarrow \text { or } \\
\text { absent expr.) }\end{array}$ & AR & $\begin{array}{l}\text { Infancy to } \\
\text { childhood }\end{array}$ & $\begin{array}{l}\text { Severe AI (incl. Al cytopenia, severe IBD, type } 1 \\
\text { diabetes mellitus), severe (EBV-induced) } \\
\text { lymphoproliferation with generalised BLH and } \\
\text { lymphocytic infiltration of organs (eg, kidney, brain), } \\
\text { IIP, GLILD, granulomata, chronic lung disease, } \\
\text { bronchiectasis, splenomegaly, hepatomegaly, } \\
\text { malignancy, finger clubbing, failure to thrive, RTI, GI } \\
\text { infections, opportunistic infections, bacterial skin } \\
\text { infections, deep abscesses, bacterial conjunctivitis, } \\
\text { warts, mollusca contagiosa, food allergy, allergic } \\
\text { dermatitis, urticaria, growth hormone deficiency. }\end{array}$ & 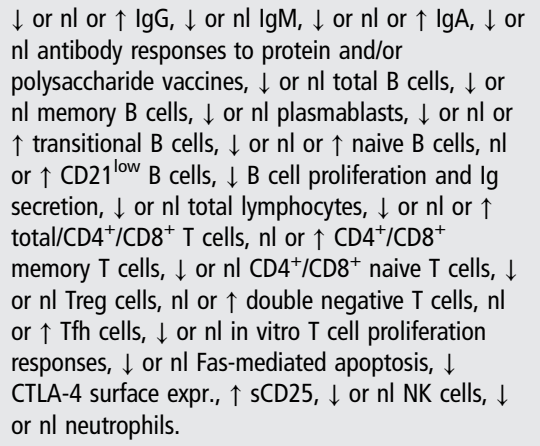 & LRBA deficiency & $5962-72$ \\
\hline $\begin{array}{l}\text { CTLA4, } \\
{ }^{\prime} 123890\end{array}$ & $\begin{array}{l}23(12 \\
\text { fam.) }\end{array}$ & $\begin{array}{l}\text { LOF (usually } \downarrow \\
\text { expr.) }\end{array}$ & $A D$ & $\begin{array}{l}\text { Infancy to } \\
\text { adulthood }\end{array}$ & $\begin{array}{l}\text { Severe AI (incl. Al cytopenia, severe IBD, type } 1 \\
\text { diabetes mellitus), severe (EBV-induced) } \\
\text { lymphoproliferation with generalised BLH and } \\
\text { lymphocytic infiltration of organs (eg, kidney, brain, } \\
\text { bone marrow), GLILD, granulomata, bronchiectasis, } \\
\text { splenomegaly, hepatomegaly, malignancy, failure to } \\
\text { thrive, RTI, GI infections, opportunistic infections, } \\
\text { pulmonary tuberculosis, warts, food allergy, allergic } \\
\text { dermatitis. } \\
\text { Note: variants also found in asymptomatic individuals. }\end{array}$ & 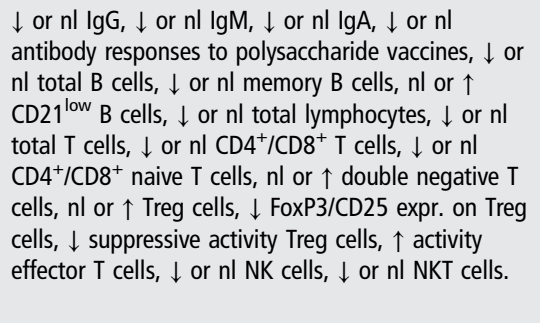 & CTLA-4 deficiency & 60617374 \\
\hline \multicolumn{9}{|c|}{ Genes encoding intracellular signalling molecules } \\
\hline $\begin{array}{l}P R K C D \\
* 176977\end{array}$ & 6 (4 fam.) & $\begin{array}{l}\text { LOF }(\downarrow \text { or absent } \\
\text { expr.) }\end{array}$ & AR & $\begin{array}{l}\text { Infancy to } \\
\text { early } \\
\text { childhood }\end{array}$ & $\begin{array}{l}\text { Severe systemic AI with features reminiscent of } \\
\text { systemic lupus erythematosus, severe (EBVI } \\
\text { CMV-induced) lymphoproliferation with generalised } \\
\text { BLH, splenomegaly, hepatomegaly, RTI, GI infections, } \\
\text { urinary tract infections, failure to thrive. }\end{array}$ & 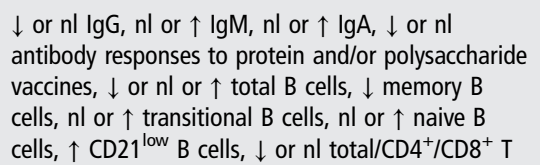 & PKC $\delta$ deficiency & 75 80-82 \\
\hline
\end{tabular}


Table 1 Continued

\begin{tabular}{|c|c|c|c|c|c|}
\hline $\begin{array}{l}\text { Gene, OMIM } \\
\text { number }\end{array}$ & $\begin{array}{l}\text { Number of } \\
\text { publ. } \\
\text { patients }\end{array}$ & Effect on protein & Inheritance & Onset & Clinical spectrum \\
\hline $\begin{array}{l}P L C G 2, \\
{ }^{*} 600220\end{array}$ & 30 (4 fam.) & $\begin{array}{l}\text { GOF (usually nl } \\
\text { expr.) }\end{array}$ & $A D$ & $\begin{array}{l}\text { Infancy to } \\
\text { childhood }\end{array}$ & $\begin{array}{l}\text { Cold urticaria (negative ice cube skin test, positive } \\
\text { evaporative cooling skin test), atopy (food, airway, } \\
\text { skin), skin granulomata, blistering skin lesions, RTI, } \\
\text { onychomycosis, varicella zoster infections, bacterial } \\
\text { skin infections, Al (mainly involving skin and thyroid } \\
\text { gland). }\end{array}$ \\
\hline $\begin{array}{l}\text { NFKB2, } \\
{ }^{*} 164012\end{array}$ & $\begin{array}{l}17(10 \\
\text { fam.) }\end{array}$ & LOF ( $\downarrow$ or $n l$ expr.) & $A D$ & $\begin{array}{l}\text { Infancy to } \\
\text { childhood }\end{array}$ & $\begin{array}{l}\text { RTI, GI infections, localised herpes simplex infections, } \\
\text { onychomycosis, bronchiectasis, pituitary hormone } \\
\text { deficiencies (mainly ACTH deficiency), AI (mainly } \\
\text { involving skin, hair and nails). }\end{array}$ \\
\hline
\end{tabular}

Immunological spectrum

cells, $\mathrm{nl}$ or $\uparrow$ double negative $T$ cells, mildly $\downarrow$ or $\mathrm{n}$ in vitro $T$ cell proliferation responses, $\downarrow$ or $n \backslash$ NK cells, $\downarrow$ or $n$ NK cell cytotoxity, nI NKT cells, $\downarrow$ or cells, $\downarrow$ or $\mathrm{nl}$ NK cell cytotoxicity, nl NKT cells, $\downarrow$ or
neutrophil microbial killing capacity.

$\downarrow$ or $\mathrm{nl} \operatorname{lgG}, \downarrow$ or $\mathrm{nl} \operatorname{lgM}, \downarrow$ or $\mathrm{nl} \operatorname{lgA}, \mathrm{nl}$ or $\uparrow \lg \mathrm{E}, \downarrow \quad$ PLAID or $\mathrm{nl}$ antibody responses to polysaccharide vaccines, $\mathrm{nl}$ total B cells, $\downarrow$ or $\mathrm{nl}$ memory B cells, $\downarrow$ BCR signalling, $\downarrow$ in vitro $B$ cell proliferation responses, negative cold agglutinins and cryoglobulins, positive antinuclear antibodies, nl total T cells, nI T cell 政, subsets, $\downarrow$ or $\mathrm{nl}$ NK cells, $\downarrow$ or $\mathrm{nl}$ NKT cells.
$\downarrow$ or $\mathrm{nl} \operatorname{lgG}, \downarrow$ or $\mathrm{nl} \operatorname{lgM}, \downarrow$ or $\mathrm{nl} \operatorname{lgA}, \downarrow$ or $\mathrm{nl}$ antibody responses to protein and/or polysaccharide vaccines, absent or $\downarrow$ or $\mathrm{nl} B$ cells, $\downarrow$ or $\mathrm{nl}$ memory

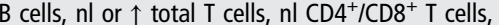
or $\mathrm{nl} \mathrm{CD4} 4^{+} / \mathrm{CD}^{+}$memory $\mathrm{T}$ cells, $\mathrm{nl}$ or $\uparrow$ recent thymic emigrant $\mathrm{CD}^{+} \mathrm{T}$ cells, $\downarrow$ or $\mathrm{nl}$ Tfh cells, $\downarrow$ or $\mathrm{nl}$ Treg cells, $\downarrow$ or $\mathrm{nl}$ in vitro $\mathrm{T}$ cell proliferation responses, $\downarrow$ or nl NK cells, $\downarrow$ or nl NK cell cytotoxicity.

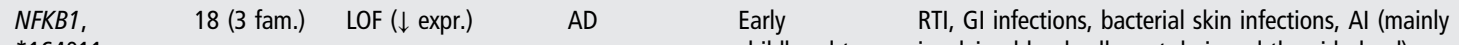
*164011 childhood to involving blood cells, gut, hair and thyroid gland), adulthood pyoderma gangrenosum, bronchiectasis, chronic lung disease, LIP, BLH, splenomegaly, hepatomegaly, disease, LIP,
malignancy.

Note: variants also found in asymptomatic individuals and in patients with other antibody deficiencies (eg, IgG subclass deficiency).

PIK3CD, $>50 \quad$ GOF (usually $\mathrm{nl} \quad \mathrm{AD} \quad$ Infancy to RTI, GI infections, bacterial skin infections, deep $\begin{array}{lll}* 602839 & \text { expr.) } & \text { early } \\ & \text { childhood } & \text { abscesses, warts, persistent CMV/EBV viraemia, failu } \\ & \text { to thrive, bronchiectasis, Al (Al cytopenia, IBD, Al }\end{array}$ primary sclerosing cholangitis), (EBV/CMV-in
lymphoproliferation with (generalised) BLH. lymphoproliferation with (generalised) BLH,
splenomegaly, hepatomegaly, malignancy (mainly lymphoma).

Full immunological phenotype not reported. antibody responses to protein and/or polysaccharide vaccines, $\mathrm{nl}$ total $\mathrm{B}$ cells, $\mathrm{nl}$ total $\mathrm{T}$ cells.

$\downarrow$ or $\mathrm{nl}$ or $\uparrow \lg \mathrm{G}, \downarrow$ or $\mathrm{nl} \operatorname{lgG} 2, \downarrow$ or $\mathrm{nl} \lg \mathrm{A}, \downarrow$ or $\mathrm{nl}$ or $\uparrow \operatorname{lgM}, \downarrow$ or $\mathrm{nl}$ antibody responses to protein and/or polysaccharide vaccines, $\downarrow$ or $\mathrm{nl}$ total B cells, absent or $\downarrow$ or $\mathrm{nl}$ memory B cells, $\mathrm{nl}$ or $\uparrow$ transitional B cells, $\downarrow$ or $\mathrm{nl}$ naive $B$ cells, $\downarrow$ or $\mathrm{nl}$ total lymphocytes, $\downarrow$ or $\mathrm{nl}$ total $/ \mathrm{CD}^{+} / \mathrm{CD} 8^{+} \mathrm{T}$ cells $\mathrm{nl}$ or $\uparrow \mathrm{CD}^{+} / \mathrm{CD}^{+}$memory T cells, $\downarrow$ or $\mathrm{nl} \mathrm{CD}^{+} /$ $\mathrm{CD}^{+}$naive T cells, $\mathrm{nl}$ Treg cells, $\uparrow \mathrm{T}$ cell activation-induced cell death, $\downarrow$ or $\mathrm{nl}$ or $\uparrow$ NK cells, $\downarrow$ or $n$ or $\uparrow$ NKT cells, $\downarrow$ or $n$ NK cell cytotoxicity. Full immunological phenotype not reported in ref

RTI, GI infections, bacterial conjunctivitis, persistent CMV/EBV viraemia, failure to thrive, bronchiectasis, Al (Al cytopenia, IBD, rheumatic disease), (EBV/ 100.

Infancy to PIK3R1
${ }^{*} 171833$ 12 (9 fam.) LOF (nl expr.) $A D$ childhood CMV-induced) lymphoproliferation with (generalised) BLH, splenomegaly ( \pm splenectomy), hepatomegaly, malignancy (mainly lymphoma).

$\downarrow$ or $\mathrm{nl} \lg \mathrm{G}, \downarrow$ or $\mathrm{nl}$ or $\uparrow \lg \mathrm{M}, \downarrow \lg \mathrm{A}, \downarrow$ antibody responses to polysaccharide vaccines, $\downarrow$ or $\mathrm{nl}$ total B cells, $\downarrow$ or $\mathrm{nl}$ memory B cells, $\mathrm{nl}$ or $\uparrow$ transitional B cells, nl or $\uparrow$ total T cells, $\downarrow$ or $\mathrm{nl} \mathrm{CD4}{ }^{+}$(total/ naive/memory) T cells, $\downarrow$ or $\mathrm{nl}$ or $\uparrow \mathrm{CD}^{+}$(total/ naive/memory) T cells, nl or $\uparrow$ Treg cells, nl double negative T cells, $\downarrow$ Th17 cells, $\downarrow$ or nl NK cells. 
Table 1 Continued

\begin{tabular}{|c|c|c|c|c|c|c|c|c|}
\hline $\begin{array}{l}\text { Gene, OMIM } \\
\text { number }\end{array}$ & $\begin{array}{l}\text { Number of } \\
\text { publ. } \\
\text { patients }\end{array}$ & Effect on protein & Inheritance & Onset & Clinical spectrum & Immunological spectrum & $\begin{array}{l}\text { CVID or separate } \\
\text { entity }\end{array}$ & Ref \\
\hline $\begin{array}{l}\text { VAV1, } \\
{ }^{*} 164875\end{array}$ & 1 & LOF ( $\downarrow$ expr.) & $A D$ & Adulthood & $\begin{array}{l}\text { Full clinical phenotype not reported. } \\
\text { RTI, GI infections, genitourinary infections, } \\
\text { bronchiectasis. }\end{array}$ & $\begin{array}{l}\text { Full immunological phenotype not reported. } \\
\downarrow l g G \text {, absent IgM/lgA, nl total B cells, nl total T } \\
\text { cells, } \downarrow \text { CD } 4^{+} T \text { cells, nl CD8 } \mathrm{T} \text { cells, } \downarrow \text { in vitro } T \\
\text { cell proliferation responses to mitogens. }\end{array}$ & Vav1 deficiency & 103 \\
\hline $\begin{array}{l}R A C 2, \\
{ }^{*} 602049\end{array}$ & 2 (1 fam.) & LOF (absent expr.) & AR & $\begin{array}{l}\text { Infancy to } \\
\text { childhood }\end{array}$ & $\begin{array}{l}\text { RTI, failure to thrive, bronchiectasis, arthralgia, AI } \\
\text { endocrinopathy, BLH, poststreptococcal } \\
\text { glomerulonephritis ( } \pm \text { progression to end-stage renal } \\
\text { disease), solar urticaria, food allergy, coagulopathy. }\end{array}$ & 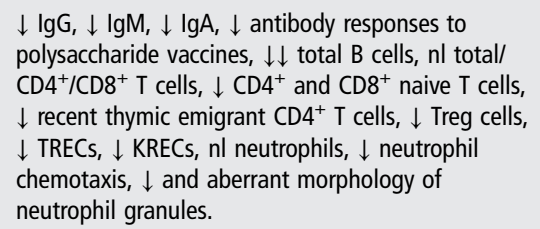 & RAC2 deficiency & 104 \\
\hline$B L K, * 191305$ & 2 (1 fam.) & LOF (nl expr.) & $A D$ & Infancy & RTI, bacterial skin infections. & $\begin{array}{l}\downarrow \operatorname{lgG}, \downarrow \text { or } \mathrm{nl} \operatorname{lgA}, \downarrow \text { or } \mathrm{nl} \operatorname{lgM}, \downarrow \text { antibody } \\
\text { responses to polysaccharide vaccines, } \downarrow \text { or } \mathrm{nl} \text { total } \\
\text { B cells, } \mathrm{nl} \text { total T cells. }\end{array}$ & CVID & 105 \\
\hline $\begin{array}{l}\text { IKZF1, } \\
{ }^{*} 603023\end{array}$ & 21 (6 fam.) & LOF ( $\downarrow$ or $\mathrm{nl}$ expr.) & $A D$ & $\begin{array}{l}\text { Early } \\
\text { childhood } \\
\text { to late } \\
\text { adulthood }\end{array}$ & $\begin{array}{l}\text { RTI, Streptococcus pneumoniae infections, GI } \\
\text { infections, bacterial skin infections, apthous ulcers, AI } \\
\text { (Al cytopenia), malignancy (acute lymphoblastic } \\
\text { leukaemia). Note: variants also found in } \\
\text { asymptomatic individuals. }\end{array}$ & $\begin{array}{l}\downarrow \operatorname{lgG}, \downarrow \text { or } \mathrm{nl} \operatorname{lgM}, \downarrow \text { or } \mathrm{nl} \operatorname{lgA}, \downarrow \text { or } \mathrm{nl} \text { antibody } \\
\text { responses to protein and/or polysaccharide vaccines, } \\
\downarrow \downarrow \text { or } \downarrow \text { or } \mathrm{nl} \text { total B cells, } \downarrow \text { or } \mathrm{nl} \text { memory B cells, } \\
\mathrm{nl} \text { or } \uparrow \text { total T cells, } \downarrow \text { or } \mathrm{nl} \text { or } \uparrow \mathrm{CD} 4^{+} \mathrm{T} \text { cells, } \mathrm{nl} \text { or } \\
\uparrow \mathrm{CD} 8^{+} \mathrm{T} \text { cells, } \mathrm{nl} \text { in vitro T cell proliferation } \\
\text { responses, nl Fas-mediated apoptosis, } \downarrow \text { or } \mathrm{nl} \text { or } \uparrow \\
\text { NK cells. }\end{array}$ & CVID & $78+$ \\
\hline $\begin{array}{l}\text { IRF2BP2, } \\
{ }^{*} 615332\end{array}$ & 3 (1 fam.) & GOF ( $\uparrow$ expr.) & $A D$ & $\begin{array}{l}\text { Early } \\
\text { childhood } \\
\text { to childhood }\end{array}$ & RTI, Al (IBD, type 1 diabetes mellitus, psoriasis). & $\begin{array}{l}\downarrow \operatorname{lgG}, \downarrow \operatorname{lgG} 2, \downarrow \text { to undetectable IgM, undetectable } \\
\text { IgA, } \downarrow \text { antibody responses to protein and/or } \\
\text { polysaccharide vaccines, nl total B cells, } \downarrow \downarrow \text { or } \downarrow \\
\text { memory B cells, nl total/CDD4 } / \text { CD8 }{ }^{+} T \text { cells, } \downarrow \text { or } \mathrm{nl} \\
\text { NK cells. }\end{array}$ & CVID & 79 \\
\hline
\end{tabular}

Disease onset: infancy ( $0-2$ years), early childhood (3-8 years), childhood (9-17 years), adulthood (18-50 years), late adulthood ( $>50$ years).

tUnpublished cases from our cohort.

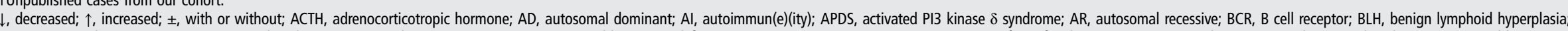
CMV, cytomegalovirus; CTLA-4, cytotoxic T lymphocyte-associated antigen 4; CVID, common variable immunodeficiency; EBV, Epstein-Barr virus; expr., expression; fam., families; Gl, gastrointestinal; GLILD, granulomatous lymphocytic interstitial lung disease; GOF, gain-of-function; HLH, hemophagocytic lymphohistiocytosis; iNKT, invariant natural killer T; IBD, inflammatory bowel disease; ICOS, inducible T cell costimulator; KRECS, $\mathrm{K}$-deleting recombination excision circles;

LRBA, lipopolysaccharide-responsive beige-like anchor protein; LIP, lymphoid interstitial pneumonia; LOF, loss-of-function; nl, normal; NFKB, nuclear factor of kappa light chain enhancer of activated B cells; OMIM, Online Mendelian Inheritance in Man;

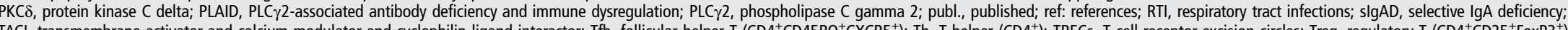

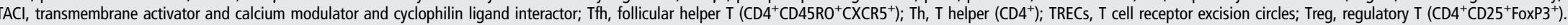




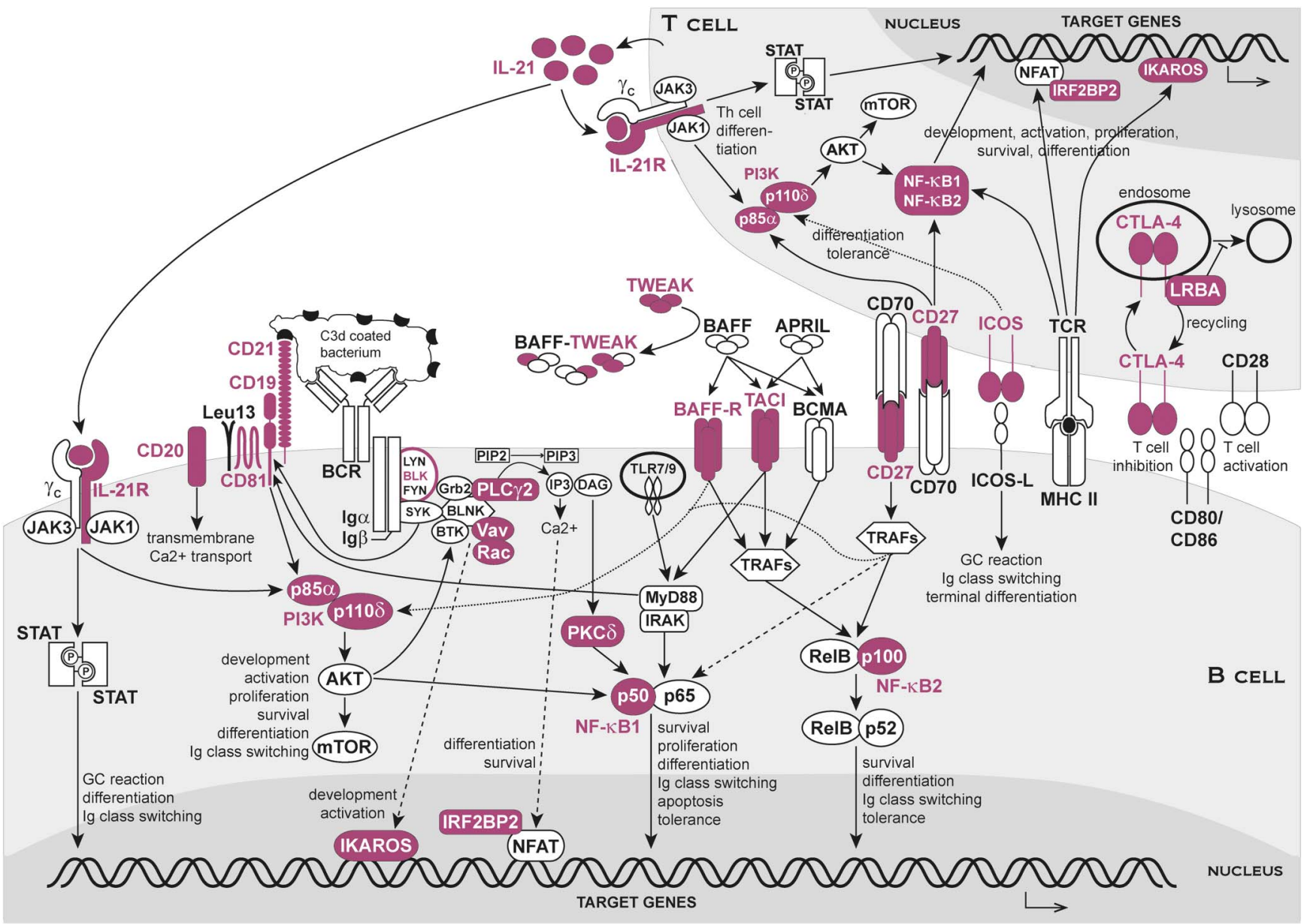

Figure 2 Scheme comprising proteins encoded by common variable immunodeficiency disease genes (purple). Only the most important interacting molecules, pathways and functions relevant to this review are depicted. See text for details.

Because of the high frequency of heterozygous TNFRSF13B variants in the general population, it is believed that these variants alone cannot explain the clinical phenotype in patients with CVID. ${ }^{18-21}$ Still, heterozygous TNFRSF13B variants can increase the risk for developing CVID by compromising B cell function and may influence the final phenotype. ${ }^{29} 30$ TACI cooperates synergistically with Toll-like receptors (TLRs) in driving B cell activation and Ig production (figure 2). ${ }^{16} \mathrm{~B}$ cells in many patients with CVID show impaired TLR7 and TLR9 responses. $^{28}$ Loss-of-function TNFRSF13B variants might aggravate the effect of already impaired TLR signalling, or, alternatively might impose TLR signalling defects. ${ }^{28}$ Furthermore, patients with CVID with heterozygous TNFRSF13B variants have a higher risk of developing autoantibody-mediated autoimmunity. ${ }^{17}{ }^{30}$ In our cohort, the daughter carrying a heterozygous C104R variant developed autoimmune cytopenias and psoriasis (unpublished data). In contrast, patients with biallelic TNFRSF13B variants seem to be protected from autoimmunity. ${ }^{30}$

\section{TNFRSF13C (encoding BAFF-R) variants}

Biallelic and monoallelic TNFRSF13C variants have been reported in about 80 patients with CVID. ${ }^{8} 2225$ 31-35 More than $90 \%$ of reported cases were heterozygous or homozygous for the P21R missense variant. ${ }^{22} 2531-35$ In addition, other patients with CVID were found to be heterozygous for H159Y, compound heterozygous for P21R and H159Y, or compound heterozygous for P21R and a complex P21R/H159Y allele. $^{25} 3132$ One patient with CVID had heterozygous P21R and $\mathrm{H} 159 \mathrm{Y}$ variants in cis. ${ }^{35}$ Interestingly, the father and sister of the last-mentioned patient also had these variants in cis but presented with isolated IgM deficiency, respectively, sIgAD. ${ }^{35}$ Moreover, heterozygous and homozygous P21R variants and heterozygous H159Y variants have also been identified in asymptomatic relatives and healthy controls. ${ }^{22} 31$ To our knowledge, biallelic variants that include $\mathrm{H} 159 \mathrm{Y}$ and the heterozygous P21R/H159Y allele in TNFRSF13C have never been reported in asymptomatic individuals. ${ }^{25} 3235$

The P21R variant reduces BAFF ligand binding (figure 2), suggestive for loss-of-function. ${ }^{22}$ In contrast, the H159Y variant has been implicated in lymphoma development and was shown to increase tumor necrosis factor receptor-associated factor (TRAF) recruitment and downstream BAFF-R signalling (figure 2) when overexpressed in a HEK293 cell line, suggestive for gain-of-function. ${ }^{36}$ Further studies will be necessary to determine the role of H159Y variants in CVID pathogenesis. The vast majority of patients with monoallelic or biallelic TNFRSF13C variants had normal BAFF-R protein expression. $^{22}{ }^{31}$ Thus far, deficiency of BAFF-R protein expression was reported in four patients with CVID. ${ }^{8} 3435$ Two of those BAFF-R-deficient patients were a brother and sister sibship born from consanguineous parents with a homozygous TNFRSF13C 24-bp deletion causing complete loss of BAFF-R expression. ${ }^{8}$ Furthermore, reduced (but not absent) BAFF-R expression was identified in one patient with CVID with a homozygous P21R 
variant and the above-mentioned patient with CVID with the heterozygous P21R/H159Y allele. ${ }^{34} 35$ In our cohort, we identified a Caucasian male patient with CVID homozygous for P21R with absent BAFF-R expression. Additional analysis is ongoing (unpublished data).

Most reported patients with CVID with TNFRSF13C variants had adulthood-onset recurrent respiratory tract infections. Nonetheless, some patients already developed symptoms at a young age and/or additionally suffered from severe CVID-related complications (table 1). $.^{8} 22 \quad 25 \quad 31-35$ Our unpublished patient presented with recurrent airway infections, chronic autoimmune thrombocytopenia and severe chronic diarrhoea at the age of 60 years. Laboratory findings varied between patients (table 1). ${ }^{8} 22 \quad 25 \quad 31-35$ Curiously, the BAFF-R-deficient sib pair and our unpublished case had important B cell lymphopenia with a relative increase in transitional B cells, which seems contradictory with their late disease onset and/or relatively mild clinical phenotype. ${ }^{8}$

Analogous to TNFRSF13B (TACI) variants, the role of TNFRSF13C (BAFF-R) variants in CVID is controversial. It is currently believed that an abnormal BAFF-R function predisposes to but does not suffice for CVID development. ${ }^{22}$

\section{TWEAK deficiency}

One CVID pedigree with autosomal dominant inheritance had a mutation in tumour necrosis factor superfamily member 12 (TNFSF12), encoding TNF-like weak inducer of apoptosis (TWEAK) (table 1). ${ }^{37}$ TWEAK mainly exerts effects on endothelial and innate immune cells. ${ }^{37}$ In addition to diminished TWEAK-induced signalling, mutant TWEAK associated with BAFF monomers thereby impeding BAFF-mediated signalling in $\mathrm{B}$ cells (figure 2). ${ }^{37}$ More patients will need to be identified to determine if TWEAK deficiency should be considered as a form of CVID or as a separate disorder.

\section{B cell co-receptor complex deficiency}

The B cell co-receptor complex is composed of four cell-surface proteins: CD19, CD21 (complement receptor 2, CR2), CD81 and Leu13 (figure 2). It lowers the threshold for B cell activation upon antigen binding to the BCR. ${ }^{38}$

CD19, CD81 and CD21 deficiencies occur in autosomal recessive forms of CVID, and were identified by use of a candidate gene approach. ${ }^{38-40}$

\section{CD19 and CD81 deficiencies}

Biallelic CD19 mutations resulting in absent CD19 surface expression have been reported in seven CVID-affected families. $^{38}{ }^{41-46}$ In an additional patient with CVID, absent CD19 surface expression was due to a biallelic CD81 splice site mutation. ${ }^{39}$ Initially, this CD81 mutation was assumed to completely abolish CD81 protein expression. ${ }^{39}$ However, it was recently demonstrated that in fact a truncated CD81 protein was produced. ${ }^{47}$ Both the mutant CD81 and the normal CD19 protein were retained intracellularly, resulting in absent CD81 and CD19 surface expression. ${ }^{47}$

All CD19-deficient patients and the CD81-deficient patient developed symptoms in early childhood and suffered from recurrent infections. $^{38} 3941-46$ Only the CD81-deficient patient showed autoimmune and inflammatory complications (table 1). ${ }^{39}$ This clinical discrepancy might be because CD81, in contrast to CD19, is involved in many immunological responses. ${ }^{39}$ All CD19-deficient and CD81-deficient patients had normal total $\mathrm{CD} 20^{+} \mathrm{B}$ cell numbers but reduced switched memory B cells. $^{38} 39{ }^{41-46}$ Impaired BCR/co-receptor complex signalling in these patients resulted in defective somatic hypermutation and CSR, as well as poor terminal differentiation into memory B cells and plasma cells. ${ }^{48}$

Interestingly, a female patient with isolated IgG1 deficiency was also found to have absent CD19 expression due to a homozygous CD19 mutation. ${ }^{45}$ She had recurrent respiratory tract infections but mainly suffered from severe IgA nephropathy. In contrast to CD19-deficient patients with CVID, memory B cells and responses to protein vaccines were normal. ${ }^{45}$ It is unclear why this CD19-deficient patient developed isolated IgG1 deficiency and not CVID. ${ }^{45}$

\section{CD21 deficiency}

Biallelic CD21 mutations causing loss of CD21 protein expression have been published in two unrelated patients with CVID. $^{40}{ }^{49}$ CD19 and CD81 expression were normal. Compared with CD19-deficient and CD81-deficient patients with CVID, CD21-deficient patients demonstrated a later age of onset, milder infections and less pronounced humoral immune defects (table 1). ${ }^{40}$ Wentink et al provided evidence that CD21-deficient patients can still mount proper B cell responses against antigenic stimuli but with reduced memory formation, whereas CD19-deficient and CD81-deficient patients have a more profoundly disturbed $\mathrm{B}$ cell response. ${ }^{49}$ On the other hand, CD21-deficient patients presented with chronic diarrhoea, splenomegaly and/or severe myalgia, which was not seen in CD19-deficient or CD81-deficient patients. ${ }^{38-46} 49$

\section{CD20 deficiency}

CD20 is part of a B cell surface complex involved in transmembrane $\mathrm{Ca}^{2+}$ transport, which is important in $\mathrm{B}$ cell signal transduction, proliferation and differentiation (figure 2)..$^{50}$ Knowledge on the exact biology of CD20 is, however, limited. CD20 is encoded by membrane-spanning 4A1 (MS4A1). Using a candidate gene approach, a homozygous MS4A1 mutation resulting in complete lack of CD20 protein expression has been identified in a single patient born from consanguineous parents. ${ }^{50}$ She did not completely fulfil diagnostic criteria for CVID as only serum IgG was decreased with normal IgM and IgA. ${ }^{50}$ She presented with early onset recurrent respiratory tract infections, markedly reduced class-switched memory B cells and impaired antibody responses to polysaccharide vaccines (table 1). ${ }^{50} \mathrm{CD} 20$ deficiency may disrupt normal $\mathrm{Ca}^{2+}$ fluxing in $\mathrm{B}$ cells thereby compromising cell cycle progression and optimal B cell activation, which may explain the CVID-like phenotype. ${ }^{50}$

\section{CD27 deficiency}

CD27, a lymphocyte surface receptor encoded by TNFRSF7, interacts with CD70 and regulates survival, function and differentiation of $\mathrm{T}, \mathrm{B}$, natural killer $(\mathrm{NK})$ and plasma cells (figure 2). ${ }^{51} \mathrm{CD} 27$ is also used as a marker of memory $\mathrm{B}$ cells, like in immunophenotypical classification of CVID. ${ }^{52}$ A homozygous TNFRSF7 mutation was first identified by targeted gene sequencing in a patient with absent CD27 protein expression. ${ }^{51}$ So far, CD27 deficiency has been reported in 17 patients of whom 15 had homozygous TNFRSF7 mutations (all from a consanguineous kindred) and one had a compound heterozygous TNFRSF7 mutation. ${ }^{51-53}$ Remarkably, in one CD27-deficient patient only a single TNFRSF7 mutation was identified, even after extensive analysis of the entire gene locus. ${ }^{52}$ The authors concluded that transcription of the second allele could be influenced by a mutation in a distant regulatory element or by other regulatory mechanisms. $^{52}$ 
The phenotype of CD27-deficient patients varied, even between those with the same genotype (table 1). ${ }^{51-53}$ Importantly, almost all CD27-deficient patients suffered from severe and/or atypical Epstein-Barr virus-associated features (table 1)..$^{51-53}$ Five patients died of disease-related complications. ${ }^{52}$ Only three of all reported patients had primary hypogammaglobulinaemia initially diagnosed as CVID. ${ }^{51-53}$ With more patients being reported, CD27 deficiency is currently considered as a lymphoproliferative syndrome distinct from CVID. ${ }^{52}$

\section{IL-21 and IL-21R deficiencies}

Interleukin 21 (IL-21) is predominantly produced by $\mathrm{T}$ cell subsets. $^{54}$ In contrast, IL-21 receptor (IL-21R) is widely expressed on lymphoid and myeloid cells and exerts pleiotropic immune functions. ${ }^{54}$ Regarding humoral immunity, IL-21-IL-21R signalling is involved in GC formation, B cell differentiation and CSR, and follicular helper T cell development (figure 2). ${ }^{54}$

Biallelic loss-of-function mutations in IL21 and IL21R were detected in consanguineous families using whole-exome sequencing (WES) combined with either homozygosity mapping or candidate gene sequencing. ${ }^{5556}$ To our knowledge, one patient with IL-21 deficiency and eight with IL-21R deficiency have been published. ${ }^{54-58}$

All IL-21(R)-deficient patients had a severe clinical presentation with high morbidity and mortality in childhood (table 1). ${ }^{54-58}$ IL-21(R)-deficient patients typically suffered from respiratory tract infections, inflammatory complications and/or opportunistic infections like Cryptosporidiosis and Pneumocystis jirovecii pneumonia. $^{54-58}$ Some IL-21(R)-deficient patients showed an aberrant B cell phenotype with reduced switched memory B cells. In addition, some patients demonstrated functional defects in T and NK cells (table 1). ${ }^{54-58}$

Several IL-21(R)-deficient patients were initially diagnosed with CVID, before the onset of opportunistic infections. ${ }^{55} 57$ However, over time it has become evident that IL-21 and IL-21R deficiencies represent forms of CID rather than CVID. ${ }^{54-58}$

\section{LRBA and CTLA-4 deficiencies}

Lipopolysaccharide-responsive beige-like anchor protein (LRBA) is a cytosolic protein localised in endoplasmatic reticulum, trans-Golgi apparatus, endocytosis vesicles and lysosomes. ${ }^{59} \mathrm{It}$ is expressed by almost all cell types with higher expression levels in immune effector cells. ${ }^{59}$ LRBA functions in polarised vesicle trafficking and polarised responses of immune effector cells, autophagy, and positive regulation of cell survival. ${ }^{59}$

CTLA-4 is an inhibitory T cell receptor (TCR) that negatively regulates immune responses. CTLA- 4 competes with the costimulatory protein $\mathrm{CD} 28$ for binding to $\mathrm{CD} 80 / \mathrm{CD} 86$, thereby preventing excessive $\mathrm{T}$ cell activation and maintaining immune tolerance (figure 2). ${ }^{60}{ }^{61}$ It was recently demonstrated that LRBA plays a role in CTLA-4 surface expression. ${ }^{62}$ LRBA is thought to rescue endosomal CTLA-4 from degradation via the lysosomal pathway and to facilitate its trafficking back to the cell surface upon TCR stimulation (figure 2). ${ }^{62}$

\section{LRBA deficiency}

Biallelic loss-of-function $L R B A$ mutations were identified by three independent groups by using linkage analysis in multiple consanguineous families or by using WES with or without homozygosity mapping in single consanguineous families. ${ }^{59} 6364$ Hitherto, biallelic LRBA mutations resulted in reduced or absent protein expression in all cases except one. ${ }^{59}{ }^{62-72}$
The clinical and immunological phenotype of LRBA-deficient patients is very variable (table 1). ${ }^{59}{ }^{62-72}$ The majority of reported LRBA-deficient patients was clinically diagnosed with CVID, some with autoimmune lymphoproliferative syndrome (ALPS)-like or immune dysregulation, polyendocrinopathy, enteropathy, X-linked-like disease. ${ }^{59}{ }^{62-72}$ A common denominator in all LRBA-deficient patients is early onset of severe autoimmunity. Other recurring clinical features are recurrent infections and severe lymphoproliferative disease with increased risk of lymphoma. ${ }^{59}{ }^{62-72}$ More than half of cases had varying degrees of hypogammaglobulinaemia and most patients had decreased switched memory B cells. ${ }^{59}$ 62-72 Importantly, LRBA deficiency is characterised by a progressive course and high mortality rate. ${ }^{59}{ }^{62-72}$ Although first identified in patients with CVID,${ }^{59}$ it is currently considered as an immune dysregulation syndrome separate from CVID. ${ }^{62-72}$

\section{CTLA-4 deficiency}

Heterozygous mutations in CTLA4 were identified by two independent groups using either WES combined with linkage analysis in a large family or WES combined with candidate gene sequencing. ${ }^{60}{ }^{61}$ Most CTLA4 mutations resulted in reduced CTLA-4 expression suggesting haploinsufficiency. $^{60} 617374$ Other CTLA4 mutations were predicted to interfere with ligand binding or protein stability, which might exert a dominant-negative effect. ${ }^{61}$ Many CTLA-4-deficient patients were clinically diagnosed with CVID. ${ }^{60} \quad 61 \quad 7374$ However, CTLA4 mutations were also detected in family members who were asymptomatic or had SIgAD, pointing to incomplete penetrance. ${ }^{60617374}$ Alternatively, the phenotype may be modulated by other disease-modifying genes and/or environmental influences. Of note, since age of onset is variable, young CTLA4 mutation carriers who are currently asymptomatic may still develop disease later in life. ${ }^{61}$

Overall, the phenotype of CTLA-4 deficiency is reminiscent of that of LRBA deficiency: autoimmunity, recurrent infections, benign lymphoproliferation, and varying Ig levels and B cell and T cell defects (table 1). ${ }^{60617374}$ Regulatory T (Treg) cells were normal in numbers but had a markedly reduced suppressive function. ${ }^{60} 617374$ Treg cells of asymptomatic CTLA4 mutation carriers also had reduced suppressive activity although they did express higher levels of CTLA-4 compared with those of their symptomatic relatives. ${ }^{60} 61$

Analogous to LRBA deficiency, CTLA-4 deficiency was first described in patients with CVID but is currently considered as a new immune dysregulation syndrome. ${ }^{60617374}$

\section{Genes encoding intracellular signalling molecules}

Protein kinase $\mathrm{C}$ delta (PKC $\delta$ ) is a key component in BCR-mediated signalling downstream of Bruton's tyrosine kinase, phospholipase C gamma 2 (PLC $\gamma 2$ ), B-lymphoid tyrosine kinase (BLK), Vav guanine nucleotide exchange factor (Vav) and Ras-related C3 botulinum toxin substrate (Rac) (figure 2). ${ }^{75}$ PKC $\delta$ propagates signalling to the nucleus by activating the canonical nuclear factor of kappa light chain enhancer of activated $\mathrm{B}$ cells $(\mathrm{NF}-\mathrm{kB})$ pathway. ${ }^{75}$ PKC $\delta$ is particularly important in $\mathrm{B}$ cell proliferation, apoptosis and tolerance. ${ }^{75}$

Class IA phosphatidyl-inositol-3-kinase (PI3K) isoforms are crucial signalling molecules downstream of various $\mathrm{B}$ cell and $\mathrm{T}$ cell surface receptors (figure 2). ${ }^{76}{ }^{77}$ Consequently, PI3K is involved in many aspects of B cell and T cell homoeostasis. ${ }^{76} 77$ The PI3K pathway activates a multitude of effector molecules and is interwoven with the PLC-PKC pathway, forming a complex signalling network (figure 2). ${ }^{76} 77$ 
The transcription factor IKAROS is a pleiotropic regulator of haematopoiesis. ${ }^{78}$ Besides key roles in T cells and non-lymphoid lineages, IKAROS is a critical regulator of B cell lymphopoiesis and function. ${ }^{78}$ IKAROS is triggered by (pre)antigen receptor signalling though the precise signalling pathways remain unclear (figure 2). ${ }^{78}$

Interferon regulatory factor 2 binding protein 2 (IRF2BP2) is thought to act as a negative regulator of the nuclear factor of activated T cells (NFAT) transcription factor (figure 2). ${ }^{79}$ In B cell biology, IRF2BP2 might play a role in the differentiation and/or survival of memory B cells and plasmablasts. ${ }^{79}$ However, its function and interactome remains obscure. ${ }^{79}$

Defects in the genes encoding PKC $\delta$, PLC $\gamma 2, \mathrm{NF}-\kappa \mathrm{B} 2$, NF- $\mathrm{BB} 1, \mathrm{PI} 3 \mathrm{~K}$ catalytic subunit $\mathrm{p} 110 \delta$, PI3K regulatory subunit $\mathrm{p} 85 \alpha$, Vav1, Rac2, BLK, IKAROS and IRFBP2 have been described in patients with CVID(-like) disease.

\section{PKC $\delta$ deficiency}

Biallelic PRKCD (encoding PKC $\delta$ ) mutations abrogating protein expression have been described in six patients from four unrelated families. ${ }^{75}$ 80-82 PRKCD was detected using WES combined with homozygosity mapping or linkage analysis in consanguineous families. ${ }^{75} 80$

PKC $\delta$ deficiency causes a variable phenotype (table 1$){ }^{75} \quad 80-82$ A CVID-like phenotype was only observed in the first-reported patient. ${ }^{75}$ The other five patients were initially diagnosed with systemic lupus erythematosus (SLE) or ALPS-like disease. ${ }^{80-82}$ Altogether, PKC $\delta$ deficiency represents a syndrome of immune dysregulation with prominent lymphoproliferation and systemic autoimmunity reminiscent of SLE. ${ }^{75}$ All patients displayed an aberrant $B$ cell phenotype with decreased switched memory B cells and increased CD $21^{\text {low }}$ B cells. ${ }^{75}{ }^{80-82}$ However, only the first-reported patient developed hypogammaglobulinaemia and, accordingly, prominent infections. ${ }^{75}$

Of interest, the first-reported PKC $\delta$-deficient patient carried an additional heterozygous CTLA4 variant (Thr17Ala, allele frequency 0.4112 ), previously associated with autoimmune thyroiditis. $^{75}$ This variant was also present in the father who had Behçet's disease and autoimmune thyroiditis. ${ }^{75}$ It cannot be excluded that this CTLA4 variant exerts a disease-modifying effect on these individuals' phenotype. ${ }^{75}$

\section{PLC $\gamma 2$-associated antibody deficiency and immune dysregulation}

PLC $\gamma 2$-associated antibody deficiency and immune dysregulation (PLAID) is a newly defined immunodeficiency syndrome caused by heterozygous gain-of-function mutations in PLCG2. ${ }^{83}{ }^{84}$ PLCG2 was identified by two independent groups, one using linkage analysis in three families combined with whole-genome sequencing (WGS) in one of those families, ${ }^{83}$ and another using WES in a multiplex family with an autosomal dominant inheritance pattern. ${ }^{84}$

PLAID is mainly characterised by cold urticaria from infancy, which is not typically seen in CVID. ${ }^{83}$ However, PLAID shares many hallmark clinical and immunological features with CVID (table 1). ${ }^{83}{ }^{84}$ Indeed, some of the initially published patients with PLAID fulfilled the diagnostic criteria of CVID. ${ }^{83}$ This phenotypical overlap might be explained by aberrant PLC $\gamma 2$ signalling downstream of the BCR and $\mathrm{Fc} \gamma$ receptors on $\mathrm{B}$ cells (figure 2). ${ }^{83}$

\section{NF- $\kappa$ B2 and NF- $\kappa$ B1 deficiencies}

The NF- $\kappa \mathrm{B}$ family of transcription factors regulates a diversity of biological processes. ${ }^{85}{ }^{86}$ The (non-canonical) NF- $\mathrm{KB} 2$ pathway is activated by a limited set of receptors, including
ICOS, TACI, BAFF-R and BCMA (figure 2). ${ }^{85} 86$ In contrast, the (canonical) NF- $\mathrm{KB} 1$ pathway is targeted by a vast number of receptors, including $\mathrm{BCR} /$ co-receptor complex, TCR and TLRs (figure 2). ${ }^{85}{ }^{86} \mathrm{NF}-\kappa \mathrm{B}$ signalling plays key roles in B cell maturation, survival, differentiation, class switching and tolerance to self-antigens. ${ }^{85} 86$

\section{NF- $\kappa B 2$ deficiency}

First described were heterozygous NFKB2 mutations detected by WES in a multiplex CVID pedigree with an autosomal dominant inheritance. ${ }^{85}$ In patients with mutant NF-кB2 (also known as NFKB p52/p100 subunit), the inactive precursor protein p100 fails to be phosphorylated and can therefore not be processed into its active form $\mathrm{p} 52$ resulting in NF-kB2 haploinsufficiency (figure 2). ${ }^{85} \quad 87-91$ Some NFKB2 mutations also appear to disrupt the canonical NF- $\mathrm{BB} 1$ pathway through a dominant-negative effect of the unprocessed p100 protein. ${ }^{87-91}$

All NF-кB2-deficient patients presented with a CVID(-like) phenotype in early childhood and suffered from recurrent respiratory tract infections. ${ }^{85}$ 87-91 About half of patients developed pituitary hormone deficiencies, which is an unusual feature in CVID. ${ }^{85}{ }^{87-91}$ Two of them had pituitary hypoplasia on brain MRI scan. ${ }^{87}$ In addition, several patients developed autoimmune manifestations involving skin, hair and/or nails. Autoimmune cytopenia, usually the predominant autoimmune manifestation in CVID, was not documented except for one child with an episode of autoimmune thrombocytopenia. ${ }^{85}$ 87-91 Furthermore, NF-кB2-deficient patients demonstrated (pan)hypogammaglobulinaemia, abnormal B cell immunophenotyping and varying degrees of $\mathrm{T}$ cell and NK cell abnormalities (table 1). ${ }^{85} 87-91$

\section{NF- $\kappa B 1$ deficiency}

Recently, heterozygous NFKB1 mutations were reported in three CVID-affected families. ${ }^{86}$ Mutant NF- $\kappa$ B1 protein (also called NFKB p50 subunit) was unstable and rapidly degraded resulting in NF-кB1 haploinsufficiency (figure 2). ${ }^{86}$ NFKB1 was identified by means of WES combined with linkage analysis in a large family with autosomal dominant inheritance. ${ }^{86}$ In contrast to NFKB2, NFKB1 mutations were also identified in relatives with milder forms of antibody deficiency (eg, sIgAD, IgG subclass deficiency) and even in some clinically healthy relatives. This could be due to incomplete penetrance, the presence of modifier genes and/or environmental factors. ${ }^{86}$

NF-кB1-deficient patients displayed a variable phenotype, different from that of NF- $\mathrm{BB} 2$-deficient patients, with variable age of onset and severity (table 1$).{ }^{86}$ The main clinical features seen in NF-кB1-deficient patients are recurrent infections, benign lymphoproliferative disease, lymphoma, and autoimmunity including autoimmune cytopenia and enteropathy. ${ }^{86}$ None had pituitary hormone deficiencies. ${ }^{86}$ Furthermore, NF-кB1deficient patients had varying degrees of hypogammaglobulinaemia, normal lymphocyte counts, and no obvious defects in innate immunity (table 1). ${ }^{86}$

\section{PI3K overactivity and deficiency \\ PI3K $p 110 \delta$ overactivity}

A heterozygous mutation in the gene encoding the PI3K catalytic subunit p110 $(P I K 3 C D)$ was initially identified in a patient with CVID in 2006 based on a mouse knockout model. ${ }^{92}$ Since 2013, heterozygous PIK3CD mutations have been described in more than 50 patients using WES. ${ }^{76} 77$ 93-97 These mutations result in overactivity of the PI3K signalling pathway evidenced by enhanced $\mathrm{p} 110 \delta$ membrane association and kinase 
activity. ${ }^{76} 77$ More than half of reported cases were heterozygous for the missense mutation E1021K. ${ }^{76} 77$ 92-97 Haplotype analysis was suggestive for a recurrent rather than for a founder mutation. $^{76}$

PI3K p1108 mutant patients showed phenotypical overlap with many other PID syndromes; the majority was diagnosed with CVID, CID or hyper-IgM syndrome. ${ }^{76} 77$ 92-97 Therefore, the phenotype associated with dominant PIK3CD gain-of-function mutations was regarded as a novel disease named activated PI3K $\delta$ syndrome (APDS). ${ }^{76}$

The clinical spectrum of APDS varies greatly (table 1). Important is the increased risk of malignancy (eg, B cell lymphoma) even in patients with a seemingly milder phenotype. $^{76} 77$ 92-97 Constitutively activated PI3K pathway causes numerous defects in $\mathrm{B}$ cell and $\mathrm{T}$ cell differentiation and function (table 1). A recurrent feature is a normal or often increased serum IgM level. ${ }^{76} 77$ 92-97

\section{PI3K p $85 \alpha$ deficiency}

Some patients with an APDS-like phenotype were found to have heterozygous loss-of-function mutations in PIK3R1, encoding the PI3K regulatory subunit p $85 \alpha$, by means of WES. ${ }^{98-101} \mathrm{Up}$ to now, all were splice site mutations resulting in loss of an exon in the domain that inhibits $\mathrm{p} 110 \delta$ catalytic activity. ${ }^{98-101}$ Loss of p $85 \alpha$-mediated inhibition of $\mathrm{p} 110 \delta$ causes hyperactivity of the PI3K signalling pathway (figure 2) explaining the APDS-like phenotype (table 1). ${ }^{98-101}$ Many of these cases were previously diagnosed with CVID. ${ }^{98-101}$

Of note, a homozygous PIK3R1 mutation causing complete loss of $\mathrm{p} 85 \alpha$ expression had been previously reported in a single patient born from consanguineous parents. ${ }^{102}$ In contrast to the above-described heterozygous splice site mutations, complete loss of $\mathrm{p} 85 \alpha$ resulted in a significant reduction of PI3K signalling causing agammaglobulinaemia and absence of B cells. ${ }^{102}$

\section{Vav1, Rac2 and BLK deficiencies}

A heterozygous Vav1 guanine nucleotide exchange factor (VAV1) mutation resulting in decreased protein expression was described in one patient diagnosed with CVID. ${ }^{103}$ Since this patient showed considerable $\mathrm{T}$ cell dysfunction (table 1), Vav1 deficiency more likely causes CID rather than CVID. ${ }^{103}$

A homozygous Ras-related C3 botulinum toxin substrate 2 (RAC2) mutation abolishing protein expression was identified in two siblings born from consanguineous parents. ${ }^{104}$ Both siblings presented with IgA deficiency that gradually evolved into CVID (table 1). ${ }^{104}$ Interestingly, heterozygous dominant-negative RAC2 mutations cause a complex neutrophil dysfunction. ${ }^{104}$ The Rac2-deficient patients with CVID showed less severe defects in neutrophil function. ${ }^{104}$

A heterozygous loss-of-function mutation in $B L K$ was detected in two related patients with CVID. ${ }^{105}$ BLK plays a role in BCR signalling and recruitment of $\mathrm{T}$ cell help (figure 2). ${ }^{105}$ This may explain the disturbed terminal $\mathrm{B}$ cell differentiation seen in these patients (table 1 ). ${ }^{105}$

More patients will need to be identified to determine if Vav1, RAC2 and BLK deficiencies should be considered as CVID or as separate disease entities.

\section{IKAROS deficiency}

Heterozygous mutations in IKZF1, encoding the transcription factor IKAROS, have been very recently identified in six CVID-affected families. ${ }^{78}$ All mutations involved the DNA-binding domain of IKAROS, resulting in failure to bind target genes and haploinsufficiency (figure 2). ${ }^{78}$ All patients with IKAROS deficiency had been diagnosed with CVID. Although there was variation in the clinical and laboratory phenotype (table 1), the majority of IKAROS-deficient patients with CVID had panhypogammaglobulinaemia and low B cell numbers with a progressive loss of serum immunoglobulins and $\mathrm{B}$ cells over time. ${ }^{78}$ In three out of six families the same genetic defect (ie, one missense variant and two large deletions) in IKZF1 was also found in asymptomatic relatives, which suggests incomplete penetrance and could be explained by modifying genetic and/or environmental factors. ${ }^{78}$ Note that most of the asymptomatic individuals were children, who might still develop a clinical phenotype at an older age. ${ }^{78}$ In our CVID cohort, we identified a sibling pair with a novel heterozygous frameshift variant in IKZF1, also located in the DNA-binding domain. The cellular phenotype of our patients is similar to that of the published cases. ${ }^{78}$ Further analysis is currently ongoing.

\section{IRF2BP2 overactivity}

Very recently, one family with an autosomal dominant pattern of CVID was identified with a heterozygous IRF2BP2 mutation cosegregating with disease. ${ }^{79}$ In vitro analyses demonstrated that the IRF2BP2 mutation impaired plasmablast differentiation of $\mathrm{B}$ cells. $^{79}$ Furthermore, subjects with the heterozygous IRF2BP2 mutation had increased levels of the corresponding transcripts and protein. ${ }^{79}$ The findings are suggestive for a gain-of-function mutation and for an augmented repression of NFAT transcriptional activity by IRF2BP2 (figure 2). ${ }^{79}$ However, additional studies are needed to uncover the mechanism by which the IRF2BP2 mutation disturbs B cell biology and causes a CVID phenotype. $^{79}$

All patients with the heterozygous IRF2BP2 mutation were diagnosed with CVID in childhood. The main phenotypical features were recurrent sinopulmonary infections, decreased IgG (mainly IgG2), low to undetectable $\operatorname{IgA}$ and IgM levels, and very low memory B cells (table 1$)^{79}$ They did not display evidence of $\mathrm{T}$ cell dysfunction. $^{79}$

\section{Genes associated with other PID disorders}

The first disease stages of other PID syndromes may sometimes resemble CVID. In fact, a large number of well defined PID disorders can be accompanied by antibody deficiency sometimes mimicking CVID. ${ }^{106}$ Mutations in GATA2, RAG1, JAK3 and DCLRE1C (encoding ARTEMIS), genes associated with other well defined PID disorders, were recently described in patients with a prior diagnosis of CVID. ${ }^{107-111}$

Autosomal dominant loss-of-function mutations in GATA2 cause a PID syndrome typically characterised by decreased monocytes, B cells, NK cells and dendritic cells, myelodysplasia, opportunistic infections and lymphoedema. ${ }^{107}$ In a recent report, a boy with a heterozygous GATA2 mutation presented with hypogammaglobulinaemia and defective antibody responses in early childhood diagnosed as CVID. ${ }^{107}$ However, during adolescence his monocyte and lymphocyte counts rapidly dropped resulting in a full-blown GATA2 deficiency syndrome. ${ }^{107}$

Autosomal recessive loss-of-function mutations in RAG1/ $R A G 2, J A K 3$ and DCLRE1C are historically associated with severe combined immune deficiency, but hypomorphic mutations are known to cause a more insidious clinical picture. ${ }^{108-}$ 111 Occasionally, patients can present with early onset antibody deficiency, impaired vaccine responses and (sub)normal lymphocyte counts eliciting a diagnosis of CVID as demonstrated in recent publications. ${ }^{108-111}$ These patients gradually developed a more severe phenotype leading to reconsideration of the prior 
CVID diagnosis and identification of biallelic mutations in RAG1, JAK3 or DCLRE1C. ${ }^{108-111}$

\section{Genetic workup in monogenic CVID}

To date, there are no clinical guidelines regarding the genetic workup of patients presenting with CVID. Genetic assessment should at least be considered in patients with severe complications since this may be important to guide treatment and follow-up (eg, LRBA/CTLA-4 deficiency, APDS). ${ }^{62} 77 \quad 9498$ Patients with monogenic CVID would also benefit from genetic testing to support genetic counselling and reproductive options.

A monogenic cause of CVID is more likely in case of early disease onset (eg, presenting in infancy or early childhood), a positive family history or consanguinity. Most of the known monogenic forms result in decreased or absent expression of a specific protein which might direct genetic testing. Still, normal protein expression does not exclude a functional defect. If only one or a limited number of CVID genes are suspected based on the patient's phenotype (table 1), we recommend protein expression analysis (if applicable) in combination with targeted testing of a single CVID gene or of a gene panel ${ }^{112}$ (in case of more than one possible gene). However, taking into account the large genetic heterogeneity of monogenic CVID as well as the large phenotypical overlap with other PID syndromes, clinical WES $^{113}$ will be likely recommended in the majority of suspected monogenic CVID cases. WGS is currently not employed for routine clinical purposes, but shows great potential as a clinical NGS tool. ${ }^{114}$

\section{COMPLEX FORMS OF CVID}

\section{CVID, a complex disorder?}

It is increasingly believed that besides rare monogenic forms, CVID is a polygenic or multifactorial disorder. This is based on the following: (1) identification of pathogenic mutations in only $2-10 \%$ of patients with CVID despite tremendous efforts, (2) large phenotypical variability between patients with the same primary genotype, (3) presence of variants in asymptomatic relatives and/or in the general population above a certain threshold frequency, (4) sporadic occurrence in about $90 \%$ of cases and (5) delayed disease onset in many patients. $^{4} 91931606186115116$

Widespread use of NGS technologies has fuelled the idea of a possible polygenic nature of CVID. ${ }^{4}{ }^{9} \quad 115 \quad 116$ Van Schouwenburg et $a l^{4}$ performed WGS in 32 sporadic patients with CVID and one grandmother-grandson pair combined with RNA sequencing of B cells in 3 sporadic patients. They observed that all patients had variants in multiple genes associated with CVID or other PID syndromes as well as an enrichment of variants in pathways important in B cell function. ${ }^{4}$ An average of 9.4 (range 5-15) variants possibly associated with CVID were found in each patient. ${ }^{4}$ Interestingly, predicted deleterious variants were identified in numerous genes not previously associated with CVID such as PRRC2A, LILRB5, PSMB9, TNIP1, ARID3A, INPP5D, SH3BP2, BANK1, GAB2, CAMLG, BCL2L11 and $E B F 1 .{ }^{4}$ Note that functional validation studies are still necessary to determine the contribution of these variants to CVID development.

In a study on a monozygotic twin pair discordant for CVID, the CVID-twin demonstrated impaired DNA demethylation in key B cell genes such as PIK3CD, RPS6KB2, BCL2L1, TCF3, CORO1B/PTPRCAP, KCNN4 and KCNC4. ${ }^{117}$ The B cell genes that were hypermethylated in the CVID-twin covered diverse functions of $\mathrm{B}$ cell biology. ${ }^{117}$ Subsequent analysis of a larger CVID and healthy control cohort confirmed that CVID B cells had a reduced ability to demethylate these key genes during differentiation from naive to memory B cells. ${ }^{117}$ DNA methylation is an epigenetic mechanism to control gene expression and can be influenced by environmental factors like smoking and infections. ${ }^{117}$ The altered DNA methylation patterns in CVID B cells implicate a role for epigenetic and/or environmental factors in CVID pathogenesis. ${ }^{117}$

\section{Variants associated with CVID}

Certain variants seem to occur more frequently in patients with CVID and may thus be a risk factor to disease development, although they do not suffice to establish a complete phenotype. Such variants have been reported in DNA repair genes (eg, MSH5), ${ }^{118}$ and in FCGR2A. ${ }^{119}$ Furthermore, in individual patients with CVID, certain variants may influence the development of specific disease features like enteropathy or autoimmunity. $^{120-122}$

\section{Genome-wide association studies}

Genome-wide association studies (GWAS) from 2011 (363 patients with CVID, 3031 controls) found an association with the human leukocyte antigen (HLA) region, consistent with findings from prior linkage studies. ${ }^{116} 123$ These researchers also identified a suggestive but non-significant association with a chromosome $8 \mathrm{p}$ locus containing ADAM28, ADAM7, ADAMDEC1 and STC1. ${ }^{116}$ In addition, patients with CVID demonstrated an increased total copy number variation burden, suggesting a role for genomic instability in CVID pathogenesis. ${ }^{116}$ Intraexonic duplications in ORC4L were found to be most highly associated with CVID. ${ }^{116}$ GWAS in healthy Chinese men $(n=3495)$ showed an association between serum IgG and the locus containing TNFRSF13B (encoding TACI). ${ }^{124}$ However, the 2011 GWAS did not detect associations with the TNFRSF13B locus. ${ }^{116}$

A GWAS from 2015 (778 patients with CVID, 10999 controls) confirmed association with the HLA locus and also found associations with loci containing CD21, ICOS, MSH5, TNFRSF13B and CLEC16A. ${ }^{9}$ The CLEC16A locus had previously been associated with autoimmune disorders. ${ }^{9}$ CLEC16A might provide a link between autoimmunity and $\mathrm{B}$ cell deficiency in CVID. ${ }^{9}$

\section{GENERAL CONCLUSION}

The genetic basis of CVID is gradually being unravelled mainly by the identification of disease genes for monogenic forms. However, these only explain $2-10 \%$ of patients with CVID. The role of modifier genes and environmental factors in complex forms of CVID will need to be further explored.

Contributors Each author listed on the manuscript has seen and approved the submission of this version of the manuscript and takes full responsibility for the manuscript. DJAB, the first author, conceptualised the review, performed a detailed literature study and wrote the first draft of the manuscript. MD, BNL, KYV and EDB critically reviewed and revised the manuscript. $\mathrm{FH}$, the last author, conceptualised the review and critically reviewed and revised the manuscript.

Funding DJAB is a PhD fellow and EDB and KYV are senior clinical investigators of the Research Foundation-Flanders (FWO).

Competing interests None declared.

Provenance and peer review Commissioned; externally peer reviewed.

\section{REFERENCES}

1 Modell V, Quinn J, Orange J, Notarangelo LD, Modell F. Primary immunodeficiencies worldwide: an updated overview from the Jeffrey Modell Centers Global Network. Immunol Res 2016;64:736-53. 
2 Bonilla FA, Barlan I, Chapel H, Costa-Carvalho BT, Cunningham-Rundles C, de la Morena MT, Espinosa-Rosales FJ, Hammarström L, Nonoyama S, Quinti I, Routes JM, Tang ML, Warnatz K. International Consensus Document (ICON): Common Variable Immunodeficiency Disorders. J Allergy Clin Immunol Pract 2016;4:38-59.

3 Tseng CW, Lai KL, Chen DY, Lin CH, Chen HH. The incidence and prevalence of common variable immunodeficiency disease in Taiwan, a population-based study. PLOS ONE 2015;10:e0140473.

4 van Schouwenburg PA, Davenport EE, Kienzler AK, Marwah I, Wright B, Lucas M, Malinauskas T, Martin HC, Lockstone HE, Cazier JB, Chapel HM, Knight JC, Patel SY. Application of whole genome and RNA sequencing to investigate the genomic landscape of common variable immunodeficiency disorders. Clin Immunol 2015; 160:301-14.

5 Grimbacher B, Hutloff A, Schlesier M, Glocker E, Warnatz K, Dräger R, Eibel H, Fischer B, Schäffer AA, Mages HW, Kroczek RA, Peter HH. Homozygous loss of ICOS is associated with adult-onset common variable immunodeficiency. Nat Immunol 2003;4:261-8.

6 Castigli E, Wilson SA, Garibyan L, Rachid R, Bonilla F, Schneider L, Geha RS. $\mathrm{TACl}$ is mutant in common variable immunodeficiency and IgA deficiency. Nat Genet 2005;37:829-34.

7 Salzer U, Chapel HM, Webster AD, Pan-Hammarström Q, Schmitt-Graeff A, Schlesier M, Peter HH, Rockstroh JK, Schneider P, Schäffer AA, Hammarström L, Grimbacher B. Mutations in TNFRSF13B encoding TACl are associated with common variable immunodeficiency in humans. Nat Genet 2005;37:820-8

8 Warnatz K, Salzer U, Rizzi M, Fischer B, Gutenberger S, Böhm J, Kienzler AK, Pan-Hammarström Q, Hammarström L, Rakhmanov M, Schlesier M, Grimbacher B, Peter $\mathrm{HH}$, Eibel $\mathrm{H}$. B-cell activating factor receptor deficiency is associated with an adult-onset antibody deficiency syndrome in humans. Proc Natl Acad Sci USA 2009;106:13945-50.

9 Li J, Jørgensen SF, Maggadottir SM, Bakay M, Warnatz K, Glessner J, Pandey R, Salzer U, Schmidt RE, Perez E, Resnick E, Goldacker S, Buchta M, Witte T, Padyukov L, Videm V, Folseraas T, Atschekzei F, Elder JT, Nair RP, Winkelmann J, Gieger $C$, Nöthen MM, Büning $C$, Brand S, Sullivan $K E$, Orange JS, Fevang B, Schreiber S, Lieb W, Aukrust P, Chapel H, Cunningham-Rundles C, Franke A, Karlsen $\mathrm{TH}$, Grimbacher B, Hakonarson $\mathrm{H}$, Hammarstrom L, Ellinghaus E. Association of CLEC16A with human common variable immunodeficiency disorder and role in murine B cells. Nat Commun 2015;6:6804.

10 Salzer U, Maul-Pavicic A, Cunningham-Rundles C, Urschel S, Belohradsky BH, Litzman J, Holm A, Franco JL, Plebani A, Hammarstrom L, Skrabl A, Schwinger W, Grimbacher B. ICOS deficiency in patients with common variable immunodeficiency. Clin Immunol 2004;113:234-40.

11 Takahashi N, Matsumoto K, Saito H, Nanki T, Miyasaka N, Kobata T, Azuma M, Lee SK, Mizutani S, Morio T. Impaired CD4 and CD8 effector function and decreased memory T cell populations in ICOS-deficient patients. J Immunol 2009;182:5515-27.

12 Chou J, Massaad MJ, Cangemi B, Bainter W, Platt C, Badran YR, Raphael BP, Kamin DS, Goldsmith JD, Pai SY, Al-Herz W, Geha RS. A novel mutation in ICOS presenting as hypogammaglobulinemia with susceptibility to opportunistic pathogens. J Allergy Clin Immunol 2015;136:794-97.e1.

13 Robertson N, Engelhardt KR, Morgan NV, Barge D, Cant AJ, Hughes SM, Abinun M, Xu Y, Koref MS, Arkwright PD, Hambleton S. Astute clinician report: a novel 10 bp frameshift deletion in exon 2 of ICOS causes a combined immunodeficiency associated with an enteritis and hepatitis. J Clin Immunol 2015;35:598-603.

14 Warnatz K, Bossaller L, Salzer U, Skrabl-Baumgartner A, Schwinger W, van der Burg M, van Dongen JJ, Orlowska-Volk M, Knoth R, Durandy A, Draeger R, Schlesier M, Peter HH, Grimbacher B. Human ICOS deficiency abrogates the germinal center reaction and provides a monogenic model for common variable immunodeficiency. Blood 2006;107:3045-52.

15 Mudter J, Wirtz S, Weigmann B, Tiede I, Tubbe I, Kiesslich R, Galle PR, Lehr HA, Neurath MF. Crohn's-like colitis in a patient with immunodeficiency associated with a defect in expression of inducible costimulator. Dig Dis Sci 2006;51:711-7.

16 Rickert RC, Jellusova J, Miletic AV. Signaling by the tumor necrosis factor receptor superfamily in B-cell biology and disease. Immunol Rev 2011;244:115-33.

17 Zhang Y, Li J, Zhang YM, Zhang XM, Tao J. Effect of TACl signaling on humoral immunity and autoimmune diseases. J Immunol Res 2015;2015:247426.

18 Castigli E, Wilson S, Garibyan L, Rachid R, Bonilla F, Schneider L, Morra M, Curran $\mathrm{J}$, Geha R. Reexamining the role of TACl coding variants in common variable immunodeficiency and selective IgA deficiency. Nat Genet 2007;39:430-1.

19 Pan-Hammarström Q, Salzer U, Du L, Björkander J, Cunningham-Rundles C, Nelson DL, Bacchelli C, Gaspar HB, Offer S, Behrens TW, Grimbacher B, Hammarström L. Reexamining the role of TACl coding variants in common variable immunodeficiency and selective IgA deficiency. Nat Genet 2007;39:429-30.

20 Salzer U, Bacchelli C, Buckridge S, Pan-Hammarström Q, Jennings S, Lougaris V, Bergbreiter A, Hagena T, Birmelin J, Plebani A, Webster AD, Peter HH, Suez D, Chapel H, McLean-Tooke A, Spickett GP, Anover-Sombke S, Ochs HD, Urschel S, Belohradsky BH, Ugrinovic S, Kumararatne DS, Lawrence TC, Holm AM, Franco JL, Schulze I, Schneider P, Gertz EM, Schäffer AA, Hammarström L, Thrasher AJ, Gaspar HB, Grimbacher B. Relevance of biallelic versus monoallelic TNFRSF13B mutations in distinguishing disease-causing from risk-increasing TNFRSF13B variants in antibody deficiency syndromes. Blood 2009;113:1967-76.
21 Martinez-Gallo M, Radigan L, Almejún MB, Martínez-Pomar N, Matamoros N, Cunningham-Rundles C. TACl mutations and impaired B-cell function in subjects with CVID and healthy heterozygotes. J Allergy Clin Immunol 2013;131:468-76.

22 Pieper K, Rizzi M, Speletas M, Smulski CR, Sic H, Kraus H, Salzer U, Fiala GJ, Schamel WW, Lougaris V, Plebani A, Hammarstrom L, Recher M, Germenis AE, Grimbacher B, Warnatz K, Rolink AG, Schneider P, Notarangelo LD, Eibel H. A common single nucleotide polymorphism impairs B-cell activating factor receptor's multimerization, contributing to common variable immunodeficiency. J Allergy Clin Immunol 2014;133:1222-25.e10.

23 Lougaris V, Gallizzi R, Vitali M, Baronio M, Salpietro A, Bergbreiter A, Salzer U, Badolato R, Plebani A. A novel compound heterozygous TACI mutation in an autosomal recessive common variable immunodeficiency (CVID) family. Hum Immunol 2012;73:836-9.

24 Martinez-Pomar N, Detková D, Arostegui Jl, Alvarez A, Soler-Palacin P, Vidaller A, Espanol T, Sampalo A, de Gracia J, Hernandez M, Yagüe J, Matamoros N. Role of TNFRSF13B variants in patients with common variable immunodeficiency. Blood 2009;114:2846-8.

25 Kutukculer N, Gulez N, Karaca NE, Aksu G, Berdeli A. Three different classifications, B lymphocyte subpopulations, TNFRSF13B (TACI), TNFRSF13C (BAFF-R), TNFSF13 (APRIL) gene mutations, CTLA-4 and ICOS gene polymorphisms in Turkish patients with common variable immunodeficiency. J Clin Immunol 2012:32:1165-79.

26 Mohammadi J, Liu C, Aghamohammadi A, Bergbreiter A, Du L, Lu J, Rezaei N, Amirzargar AA, Moin M, Salzer U, Pan-Hammarström Q, Hammarström L. Novel mutations in TACI (TNFRSF13B) causing common variable immunodeficiency. J Clin Immunol 2009:29:777-85.

27 Speletas M, Mamara A, Papadopoulou-Alataki E, lordanakis G, Liadaki K, Bardaka F, Kanariou M, Germenis AE. TNFRSF13B/TACI alterations in Greek patients with antibody deficiencies. J Clin Immunol 2011;31:550-9.

28 Almejun MB, Cols M, Zelazko M, Oleastro M, Cerutti A, Oppezzo P, Cunningham-Rundles $C$, Danielian $S$. Naturally occurring mutation affecting the MyD88-binding site of TNFRSF13B impairs triggering of class switch recombination. Eur J Immunol 2013;43:805-14.

29 Sathkumara HD, De Silva NR, Handunnetti S, De Silva AD. Genetics of common variable immunodeficiency: role of transmembrane activator and calcium modulator and cyclophilin ligand interactor. Int J Immunogenet 2015;42:239-53.

30 Romberg N, Chamberlain N, Saadoun D, Gentile M, Kinnunen T, Ng YS, Virdee M, Menard L, Cantaert T, Morbach H, Rachid R, Martinez-Pomar N, Matamoros N, Geha R, Grimbacher B, Cerutti A, Cunningham-Rundles C, Meffre E. CVID-associated TACI mutations affect autoreactive $B$ cell selection and activation. J Clin Invest 2013;123:4283-93.

31 Losi CG, Silini A, Fiorini C, Soresina A, Meini A, Ferrari S, Notarangelo LD, Lougaris $V$, Plebani A. Mutational analysis of human BAFF receptor TNFRSF13C (BAFF-R) in patients with common variable immunodeficiency. J Clin Immunol 2005;25:496-502.

32 Kienzler AK, Salzer U, Warnatz K, Grimbacher B, Rolink A, Pan-Hammarstrom Q, Hammarstrom L, Peter HH, Eibel H. Human BAFF-R deficiency is associated with primary antibody deficiency syndrome. Clin Immunol 2009:131:S123-S23.

33 Ochtrop ML, Goldacker S, May AM, Rizzi M, Draeger R, Hauschke D, Stehfest C, Warnatz K, Goebel H, Technau-Ihling K, Werner M, Salzer U, Eibel H, Schlesier M, Peter $\mathrm{HH}$. T and B lymphocyte abnormalities in bone marrow biopsies of common variable immunodeficiency. Blood 2011;118:309-18.

34 Germinaro M, Reynolds P, Knight V, Alam R. Association of B-cell activating factor receptor deficiency with the $P 21 R$ polymorphism and common variable immunodeficiency. Ann Allergy Asthma Immunol 2015;115:82-3.

35 Lougaris V, Baronio M, Moratto D, Cardinale F, Plebani A. Monoallelic BAFFR P21R/H159Y Mutations and Familiar Primary Antibody Deficiencies. J Clin Immunol 2016;36:1-3.

36 Hildebrand JM, Luo Z, Manske MK, Price-Troska T, Ziesmer SC, Lin W, Hostager BS, Slager SL, Witzig TE, Ansell SM, Cerhan JR, Bishop GA, Novak AJ. A BAFF-R mutation associated with non-Hodgkin lymphoma alters TRAF recruitment and reveals new insights into BAFF-R signaling. J Exp Med 2010;207:2569-79.

37 Wang HY, Ma CA, Zhao Y, Fan X, Zhou Q, Edmonds P, Uzel G, Oliveira JB, Orange J, Jain A. Antibody deficiency associated with an inherited autosomal dominant mutation in TWEAK. Proc Natl Acad Sci USA 2013;110:5127-32.

38 van Zelm MC, Reisli I, van der Burg M, Castano D, van Noesel CJ, van Tol MJ, Woellner C, Grimbacher B, Patino PJ, van Dongen JJ, Franco JL. An antibody-deficiency syndrome due to mutations in the CD19 gene. N Engl J Med 2006;354:1901-12.

39 van Zelm MC, Smet J, Adams B, Mascart F, Schandené L, Janssen F, Ferster A, Kuo CC, Levy S, van Dongen JJ, van der Burg M. CD81 gene defect in humans disrupts CD19 complex formation and leads to antibody deficiency. J Clin Invest 2010;120:1265-74.

40 Thiel J, Kimmig L, Salzer U, Grudzien M, Lebrecht D, Hagena T, Draeger R, Volxen $N$, Bergbreiter $A$, Jennings $S$, Gutenberger $S$, Aichem A, Illges $H$, Hannan JP, Kienzler AK, Rizzi M, Eibel H, Peter HH, Warnatz K, Grimbacher B, Rump JA, Schlesier M. Genetic CD21 deficiency is associated with hypogammaglobulinemia. J Allergy Clin Immunol 2012;129:801-10.e6. 
41 Kanegane H, Agematsu K, Futatani T, Sira MM, Suga K, Sekiguchi T, van Zelm MC, Miyawaki T. Novel mutations in a Japanese patient with CD19 deficiency. Genes Immun 2007;8:663-70.

42 Conley ME, Dobbs AK, Farmer DM, Kilic S, Paris K, Grigoriadou S, Coustan-Smith E, Howard V, Campana D. Primary B cell immunodeficiencies: comparisons and contrasts. Annu Rev Immunol 2009;27:199-227.

43 Artac H, Reisli I, Kara R, Pico-Knijnenburg I, Adin-Çinar S, Pekcan S, Jol-van der Zijde CM, van Tol MJ, Bakker-Jonges LE, van Dongen JJ, van der Burg M, van Zelm MC. B-cell maturation and antibody responses in individuals carrying a mutated CD19 allele. Genes Immun 2010;11:523-30.

44 van Zelm MC, Smet J, van der Burg M, Ferster $A$, Le PQ, Schandené L, van Dongen JJ, Mascart F. Antibody deficiency due to a missense mutation in CD19 demonstrates the importance of the conserved tryptophan 41 in immunoglobulin superfamily domain formation. Hum Mol Genet 2011;20:1854-63.

45 Vince N, Boutboul D, Mouillot G, Just N, Peralta M, Casanova JL, Conley ME, Bories JC, Oksenhendler E, Malphettes M, Fieschi C. Defects in the CD19 complex predispose to glomerulonephritis, as well as IgG1 subclass deficiency. J Allergy Clin Immunol 2011;127:538-41.e1-5.

46 Skendros P, Rondeau S, Chateil JF, Bui S, Bocly V, Moreau JF, Theodorou I, Aladjidi N. Misdiagnosed CD19 deficiency leads to severe lung disease. Pediatr Allergy Immunol 2014;25:603-6.

47 Vences-Catalán F, Kuo CC, Sagi Y, Chen H, Kela-Madar N, van Zelm MC, van Dongen JJ, Levy S. A mutation in the human tetraspanin CD81 gene is expressed as a truncated protein but does not enable CD19 maturation and cell surface expression. J Clin Immunol 2015;35:254-63.

48 van Zelm MC, Bartol SJ, Driessen GJ, Mascart F, Reisli I, Franco JL, Wolska-Kusnierz B, Kanegane H, Boon L, van Dongen JJ, van der Burg M. Human CD19 and CD40L deficiencies impair antibody selection and differentially affect somatic hypermutation. J Allergy Clin Immunol 2014;134:135-44.

49 Wentink MW, Lambeck AJ, van Zelm MC, Simons E, van Dongen JJ, Jlspeert $H$, Schölvinck EH, van der Burg M. CD21 and CD19 deficiency: two defects in the same complex leading to different disease modalities. Clin Immunol 2015;161:120-7.

50 Kuijpers TW, Bende RJ, Baars PA, Grummels A, Derks IA, Dolman KM, Beaumont T, Tedder TF, van Noesel CJ, Eldering E, van Lier RA. CD20 deficiency in humans results in impaired $\mathrm{T}$ cell-independent antibody responses. J Clin Invest 2010;120:214-22.

51 van Montfrans JM, Hoepelman Al, Otto S, van Gijn M, van de Corput L, de Weger RA, Monaco-Shawver L, Banerjee PP, Sanders EA, Jol-van der Zijde CM, Betts MR, Orange JS, Bloem AC, Tesselaar K. CD27 deficiency is associated with combined immunodeficiency and persistent symptomatic EBV viremia. J Allergy Clin Immunol 2012;129:787-93 e6.

52 Alkhairy OK, Perez-Becker R, Driessen GJ, Abolhassani $H$, van Montfrans J, Borte S, Choo S, Wang N, Tesselaar K, Fang M, Bienemann K, Boztug K, Daneva A, Mechinaud F, Wiesel T, Becker C, Dückers G, Siepermann K, van Zelm MC, Rezae $N$, van der Burg $M$, Aghamohammadi A, Seidel MG, Niehues T, Hammarström L. Novel mutations in TNFRSF7/CD27: Clinical, immunologic, and genetic characterization of human CD27 deficiency. J Allergy Clin Immunol 2015;136:703-12.e10

53 Salzer E, Daschkey S, Choo S, Gombert M, Santos-Valente E, Ginzel S, Schwendinger M, Haas OA, Fritsch G, Pickl WF, Förster-Waldl E, Borkhardt A, Boztug K, Bienemann K, Seidel MG. Combined immunodeficiency with life-threatening EBV-associated lymphoproliferative disorder in patients lacking functional CD27. Haematologica 2013;98:473-8.

54 Kotlarz D, Ziętara N, Milner JD, Klein C. Human IL-21 and IL-21R deficiencies: two novel entities of primary immunodeficiency. Curr Opin Pediatr 2014:26:704-12

55 Salzer E, Kansu A, Sic H, Májek P, Ikincioğullari A, Dogu FE, Prengemann NK, Santos-Valente E, Pickl WF, Bilic I, Ban SA, Kuloğlu Z, Demir AM, Ensari A, Colinge J, Rizzi M, Eibel H, Boztug K. Early-onset inflammatory bowel disease and common variable immunodeficiency-like disease caused by IL-21 deficiency. J Allergy Clin Immunol 2014;133:1651-9.e12.

56 Kotlarz D, Ziętara N, Uzel G, Weidemann T, Braun CJ, Diestelhorst J, Krawitz PM, Robinson PN, Hecht J, Puchałka J, Gertz EM, Schäffer AA, Lawrence MG, Kardava L, Pfeifer D, Baumann U, Pfister ED, Hanson EP, Schambach A, Jacobs R, Kreipe $H$, Moir S, Milner JD, Schwille P, Mundlos S, Klein C. Loss-of-function mutations in the IL-21 receptor gene cause a primary immunodeficiency syndrome. J Exp Med 2013;210:433-43.

57 Stepensky P, Keller B, Abuzaitoun O, Shaag A, Yaacov B, Unger S, Seidl M, Rizzi $\mathrm{M}$, Weintraub M, Elpeleg $\mathrm{O}$, Warnatz K. Extending the clinical and immunological phenotype of human interleukin-21 receptor deficiency. Haematologica 2015;100: e72-6.

58 Erman B, Bilic I, Hirschmugl T, Salzer E, Çagdas D, Esenboga S, Akcoren Z, Sanal O, Tezcan I, Boztug K. Combined immunodeficiency with CD4 lymphopenia and sclerosing cholangitis caused by a novel loss-of-function mutation affecting IL21R. Haematologica 2015;100:e216-9.

59 Lopez-Herrera G, Tampella G, Pan-Hammarström Q, Herholz P, Trujillo-Vargas CM Phadwal K, Simon AK, Moutschen M, Etzioni A, Mory A, Srugo I, Melamed D,
Hultenby K, Liu C, Baronio M, Vitali M, Philippet P, Dideberg V, Aghamohammadi A, Rezaei N, Enright V, Du L, Salzer U, Eibel H, Pfeifer D, Veelken $H$, Stauss $H$, Lougaris V, Plebani A, Gertz EM, Schaffer AA, Hammarström L, Grimbacher B. Deleterious mutations in LRBA are associated with a syndrome of immune deficiency and autoimmunity. Am J Hum Genet 2012;90:986-1001.

60 Kuehn HS, Ouyang W, Lo B, Deenick EK, Niemela JE, Avery DT, Schickel JN, Tran $D Q$, Stoddard J, Zhang Y, Frucht DM, Dumitriu B, Scheinberg P, Folio LR, Frein CA, Price $S$, Koh C, Heller T, Seroogy CM, Huttenlocher A, Rao VK, Su HC, Kleiner D, Notarangelo LD, Rampertaap Y, Olivier KN, McElwee J, Hughes J, Pittaluga S, Oliveira JB, Meffre E, Fleisher TA, Holland SM, Lenardo MJ, Tangye SG, Uzel G. Immune dysregulation in human subjects with heterozygous germline mutations in CTLA4. Science 2014;345:1623-7.

61 Schubert D, Bode C, Kenefeck R, Hou TZ, Wing JB, Kennedy A, Bulashevska A, Petersen BS, Schäffer AA, Grüning BA, Unger $S$, Frede N, Baumann U, Witte $T$, Schmidt RE, Dueckers $G$, Niehues $T$, Seneviratne $S$, Kanariou M, Speckmann $C$, Eh $S$, Rensing-Ehl A, Warnatz K, Rakhmanov M, Thimme R, Hasselblatt $P$, Emmerich F, Cathomen T, Backofen R, Fisch P, Seidl M, May A, Schmitt-Graeff A, Ikemizu S, Salzer U, Franke A, Sakaguchi S, Walker LS, Sansom DM, Grimbacher B. Autosomal dominant immune dysregulation syndrome in humans with CTLA4 mutations. Nat Med 2014;20:1410-6.

62 Lo B, Zhang K, Lu W, Zheng L, Zhang Q, Kanellopoulou C, Zhang Y, Liu Z, Fritz JM, Marsh R, Husami A, Kissell D, Nortman S, Chaturvedi V, Haines H, Young LR, Mo J, Filipovich AH, Bleesing JJ, Mustillo P, Stephens M, Rueda CM, Chougnet CA, Hoebe K, McElwee J, Hughes JD, Karakoc-Aydiner E, Matthews HF, Price S, Su HC, Rao VK, Lenardo MJ, Jordan MB. AUTOIMMUNE DISEASE. Patients with LRBA deficiency show CTLA4 loss and immune dysregulation responsive to abatacept therapy. Science 2015;349:436-40.

63 Alangari A, Alsultan A, Adly N, Massaad MJ, Kiani IS, Aljebreen A, Raddaoui E, Almomen AK, Al-Muhsen S, Geha RS, Alkuraya FS. LPS-responsive beige-like anchor (LRBA) gene mutation in a family with inflammatory bowel disease and combined immunodeficiency. J Allergy Clin Immunol 2012;130:481-8.e2.

64 Burns SO, Zenner HL, Plagnol V, Curtis J, Mok K, Eisenhut M, Kumararatne D, Doffinger $R$, Thrasher A, Nejentsev S. LRBA gene deletion in a patient presenting with autoimmunity without hypogammaglobulinemia. J Allergy Clin Immunol 2012;130:1428-32.

65 Charbonnier LM, Janssen E, Chou J, Ohsumi TK, Keles S, Hsu JT, Massaad MJ, Garcia-Lloret M, Hanna-Wakim R, Dbaibo G, Alangari AA, Alsultan A, Al-Zahrani $D$, Geha RS, Chatila TA. Regulatory T-cell deficiency and immune dysregulation, polyendocrinopathy, enteropathy, X-linked-like disorder caused by loss-of-function mutations in LRBA. J Allergy Clin Immunol 2015;135:217-27.

66 Revel-Vilk S, Fischer U, Keller B, Nabhani S, Gámez-Diaz L, Rensing-Ehl A, Gombert M, Hönscheid A, Saleh H, Shaag A, Borkhardt A, Grimbacher B, Warnatz K, Elpeleg O, Stepensky P. Autoimmune lymphoproliferative syndrome-like disease in patients with LRBA mutation. Clin Immunol 2015;159:84-92.

67 Seidel MG, Hirschmugl T, Gamez-Diaz L, Schwinger W, Serwas N, Deutschmann A, Gorkiewicz G, Zenz W, Windpassinger C, Grimbacher B, Urban C, Boztug K. Long-term remission after allogeneic hematopoietic stem cell transplantation in LPS-responsive beige-like anchor (LRBA) deficiency. J Allergy Clin Immunol 2015;135:1384-90.e1-8.

68 Serwas NK, Kansu A, Santos-Valente E, Kuloğlu Z, Demir A, Yaman A, Yaneth Gamez Diaz L, Artan R, Sayar E, Ensari A, Grimbacher B, Boztug K. Atypical manifestation of LRBA deficiency with predominant IBD-like phenotype. Inflamm Bowel Dis 2015;21:40-7.

69 Gámez-Diaz L, August D, Stepensky P, Revel-Vilk S, Seidel MG, Noriko M, Morio T, Worth AJ, Blessing J, Van de Veerdonk F, Feuchtinger T, Kanariou $M_{1}$ Schmitt-Graeff A, Jung S, Seneviratne S, Burns S, Belohradsky BH, Rezaei N, Bakhtiar S, Speckmann C, Jordan M, Grimbacher B. The extended phenotype of LPS-responsive beige-like anchor protein (LRBA) deficiency. J Allergy Clin Immunol 2016;137:223-30

70 Sari S, Dogu F, Hwa V, Haskologlu S, Dauber A, Rosenfeld R, Polat M, Kuloglu Z, Kansu A, Dalgic B, Ikinciogullari A. A successful HSCT in a girl with novel LRBA mutation with refractory celiac disease. J Clin Immunol 2016;36:8-11.

71 Alkhairy OK, Abolhassani H, Rezaei N, Fang M, Andersen KK, Chavoshzadeh Z, Mohammadzadeh I, El-Rajab MA, Massaad M, Chou J, Aghamohammadi A, Geha RS, Hammarström L. Spectrum of Phenotypes Associated with Mutations in LRBA. J Clin Immunol 2016;36:33-45.

72 Schreiner F, Plamper M, Dueker G, Schoenberger S, Gámez-Díaz L, Grimbacher B, Hilger AC, Gohlke B, Reutter H, Woelfle J. Infancy-onset T1DM, short stature, and severe immunodysregulation in two siblings with a homozygous LRBA mutation. J Clin Endocrinol Metab 2016;101:898-904.

73 Hayakawa S, Okada S, Tsumura M, Sakata S, Ueno Y, Imai K, Morio T, Ohara O, Chayama K, Kobayashi M. A Patient with CTLA-4 Haploinsufficiency Presenting Gastric Cancer. J Clin Immunol 2016;36:28-32.

74 Zeissig S, Petersen BS, Tomczak M, Melum E, Huc-Claustre E, Dougan SK, Laerdahl JK, Stade B, Forster M, Schreiber S, Weir D, Leichtner AM, Franke A, Blumberg RS. Early-onset Crohn's disease and autoimmunity associated with a variant in CTLA-4. Gut 2015;64:1889-97. 
75 Salzer E, Santos-Valente E, Klaver S, Ban SA, Emminger W, Prengemann NK, Garncarz W, Müllauer L, Kain R, Boztug H, Heitger A, Arbeiter K, Eitelberger F, Seidel MG, Holter W, Pollak A, Pickl WF, Förster-Waldl E, Boztug K. B-cell deficiency and severe autoimmunity caused by deficiency of protein kinase $C$ delta. Blood 2013;121:3112-6.

76 Angulo I, Vadas O, Garçon F, Banham-Hall E, Plagnol V, Leahy TR, Baxendale H, Coulter T, Curtis J, Wu C, Blake-Palmer K, Perisic O, Smyth D, Maes M, Fiddler C, Juss J, Cilliers D, Markeli G, Chandra A, Farmer G, Kielkowska A, Clark J, Kracker S, Debré M, Picard C, Pellier I, Jabado N, Morris JA, Barcenas-Morales G, Fischer A, Stephens L, Hawkins P, Barrett JC, Abinun M, Clatworthy M, Durandy A, Doffinger R, Chilvers ER, Cant AJ, Kumararatne D, Okkenhaug K, Williams RL, Condliffe A, Nejentsev $\mathrm{S}$. Phosphoinositide 3-kinase delta gene mutation predisposes to respiratory infection and airway damage. Science 2013;342:866-71.

77 Lucas CL, Kuehn HS, Zhao F, Niemela JE, Deenick EK, Palendira U, Avery DT, Moens L, Cannons JL, Biancalana M, Stoddard J, Ouyang W, Frucht DM, Rao VK, Atkinson TP, Agharahimi A, Hussey AA, Folio LR, Olivier KN, Fleisher TA, Pittaluga S, Holland SM, Cohen Jl, Oliveira JB, Tangye SG, Schwartzberg PL, Lenardo MJ, Uzel G. Dominant-activating germline mutations in the gene encoding the PI(3)K catalytic subunit p1108 result in T cell senescence and human immunodeficiency. Nat Immunol 2014;15:88-97.

78 Kuehn HS, Boisson B, Cunningham-Rundles C, Reichenbach J, Stray-Pedersen A, Gelfand EW, Maffucci P, Pierce KR, Abbott JK, Voelkerding KV, South ST, Augustine NH, Bush JS, Dolen WK, Wray BB, Itan Y, Cobat A, Sorte HS, Ganesan $S$, Prader S, Martins TB, Lawrence MG, Orange JS, Calvo KR, Niemela JE, Casanova JL, Fleisher TA, Hill HR, Kumanovics A, Conley ME, Rosenzweig SD. Loss of $B$ Cells in Patients with Heterozygous Mutations in IKAROS. N Engl J Med 2016;374:1032-43.

79 Keller MD, Pandey R, Li D, Glessner J, Tian L, Henrickson SE, Chinn IK, Monaco-Shawver L, Heimall J, Hou C, Otieno FG, Jyonouchi S, Calabrese L, van Montfrans J, Orange JS, Hakonarson H. Mutation in IRF2BP2 is responsible for a familial form of common variable immunodeficiency disorder. J Allergy Clin Immunol Published Online First: 23 Mar 2016. doi:10.1016/j.jaci.2016.01.018

80 Belot A, Kasher PR, Trotter EW, Foray AP, Debaud AL, Rice Gl, Szynkiewicz M, Zabot MT, Rouvet I, Bhaskar SS, Daly SB, Dickerson JE, Mayer J, O'Sullivan J, Juillard L, Urquhart JE, Fawdar S, Marusiak AA, Stephenson N, Waszkowycz B, W Beresford M, Biesecker LG, C MBlack G, René C, Eliaou JF, Fabien N, Ranchin B, Cochat P, Gaffney PM, Rozenberg F, Lebon P, Malcus C, Crow YJ, Brognard J, Bonnefoy N. Protein kinase $c \delta$ deficiency causes Mendelian systemic lupus erythematosus with B cell-defective apoptosis and hyperproliferation. Arthritis Rheum 2013;65:2161-71.

81 Kuehn HS, Niemela JE, Rangel-Santos A, Zhang M, Pittaluga S, Stoddard JL, Hussey AA, Evbuomwan MO, Priel DA, Kuhns DB, Park CL, Fleisher TA, Uzel G, Oliveira JB. Loss-of-function of the protein kinase $\mathrm{C} \delta$ (PKC $\delta$ ) causes a B-cell lymphoproliferative syndrome in humans. Blood 2013;121:3117-25.

82 Kiykim A, Ogulur I, Baris S, Salzer E, Karakoc-Aydiner E, Ozen AO, Garncarz W, Hirschmugl T, Krolo A, Yucelten AD, Boztug K, Barlan IB. Potentially beneficial effect of hydroxychloroquine in a patient with a novel mutation in protein kinase C $\delta$ deficiency. J Clin Immunol 2015;35:523-6.

83 Ombrello MJ, Remmers EF, Sun G, Freeman AF, Datta S, Torabi-Parizi P, Subramanian N, Bunney TD, Baxendale RW, Martins MS, Romberg N, Komarow $H$, Aksentijevich I, Kim HS, Ho J, Cruse G, Jung MY, Gilfillan AM, Metcalfe DD, Nelson C, O'Brien M, Wisch L, Stone K, Douek DC, Gandhi C, Wanderer AA, Lee $\mathrm{H}$, Nelson SF, Shianna KV, Cirulli ET, Goldstein DB, Long EO, Moir S, Meffre E, Holland SM, Kastner DL, Katan M, Hoffman HM, Milner JD. Cold urticaria, immunodeficiency, and autoimmunity related to PLCG2 deletions. N Eng/ I Med 2012;366:330-8.

84 Zhou Q, Lee GS, Brady J, Datta S, Katan M, Sheikh A, Martins MS, Bunney TD, Santich BH, Moir S, Kuhns DB, Long Priel DA, Ombrello A, Stone D, Ombrello MJ, Khan J, Milner JD, Kastner DL, Aksentijevich I. A hypermorphic missense mutation in PLCG2, encoding phospholipase $C \gamma 2$, causes a dominantly inherited autoinflammatory disease with immunodeficiency. Am I Hum Genet 2012;91:713-20.

85 Chen K, Coonrod EM, Kumánovics A, Franks ZF, Durtschi JD, Margraf RL, Wu W, Heikal NM, Augustine NH, Ridge PG, Hill HR, Jorde LB, Weyrich AS, Zimmerman GA, Gundlapalli AV, Bohnsack JF, Voelkerding KV. Germline mutations in NFKB2 implicate the noncanonical NF- $\mathrm{KB}$ pathway in the pathogenesis of common variable immunodeficiency. Am J Hum Genet 2013;93:812-24.

86 Fliegauf M, V LB, Frede N, Slade C, Woon ST, Lehnert K, Winzer S, Bulashevska A, Scerri T, Leung E, Jordan A, Keller B, de Vries E, Cao H, Yang F, Schaffer AA, Warnatz $K$, Browett $P$, Douglass J, Ameratunga RV, van der Meer JW, Grimbacher B. Haploinsufficiency of the NF- $\mathrm{KB} 1$ subunit $\mathrm{p} 50$ in common variable immunodeficiency. Am J Hum Genet 2015;97:389-403.

87 Brue T, Quentien MH, Khetchoumian K, Bensa M, Capo-Chichi JM, Delemer B, Balsalobre A, Nassif C, Papadimitriou DT, Pagnier A, Hasselmann C, Patry L, Schwartzentruber J, Souchon PF, Takayasu S, Enjalbert A, Van Vliet G, Majewski J, Drouin J, Samuels ME. Mutations in NFKB2 and potential genetic heterogeneity in patients with DAVID syndrome, having variable endocrine and immune deficiencies. BMC Med Genet 2014;15:139.
88 Lee $C E$, Fulcher DA, Whittle B, Chand R, Fewings N, Field M, Andrews D, Goodnow CC, Cook MC. Autosomal-dominant B-cell deficiency with alopecia due to a mutation in NFKB2 that results in nonprocessable p100. Blood 2014;124:2964-72.

89 Lindsley AW, Qian Y, Valencia CA, Shah K, Zhang K, Assa'ad A. Combined immune deficiency in a patient with a novel NFKB2 mutation. J Clin Immunol 2014;34:910-5.

90 Liu Y, Hanson S, Gurugama P, Jones A, Clark B, Ibrahim MA. Novel NFKB2 Mutation in Early-Onset CVID. I Clin Immunol 2014;34:686-90.

91 Lougaris V, Tabellini G, Vitali M, Baronio M, Patrizi O, Tampella G, Biasini A, Moratto D, Parolini S, Plebani A. Defective natural killer-cell cytotoxic activity in NFKB2-mutated CVID-like disease. J Allergy Clin Immunol 2015;135:1641-3.

92 Jou ST, Chien YH, Yang YH, Wang TC, Shyur SD, Chou CC, Chang ML, Lin DT, Lin $\mathrm{KH}$, Chiang BL. Identification of variations in the human phosphoinositide 3-kinase p110delta gene in children with primary B-cell immunodeficiency of unknown aetiology. Int I Immunogenet 2006;33:361-9.

93 Crank MC, Grossman JK, Moir S, Pittaluga S, Buckner CM, Kardava L, Agharahimi A, Meuwissen H, Stoddard J, Niemela J, Kuehn H, Rosenzweig SD. Mutations in PIK3CD can cause hyper IgM syndrome (HIGM) associated with increased cancer susceptibility. I Clin Immunol 2014;34:272-6.

94 Hartman HN, Niemela J, Hintermeyer MK, Garofalo M, Stoddard J, Verbsky JW, Rosenzweig SD, Routes JM. Gain of function mutations of PIK3CD as a cause of primary sclerosing cholangitis. J Clin Immunol 2015;35:11-4.

95 Kracker S, Curtis J, Ibrahim MAA, Sediva A, Salisbury J, Campr V, Debré M, Edgar JDM, Imai K, Picard C, Casanova JL, Fischer A, Nejentsev S, Durandy A. Occurrence of B-cell lymphomas in patients with activated phosphoinositide 3-kinase $\delta$ syndrome. J Allergy Clin Immunol 2014;134:233-6.

96 Chiriaco M, Brigida I, Ariganello P, Di Cesare S, Di Matteo G, Taus F, Cittaro D, Lazarevic D, Scarselli A, Santilli V, Attardi E, Stupka E, Giannelli S, Fraziano M, Finocchi A, Rossi P, Aiuti A, Palma P, Cancrini C. A case of APDS patient: defects in maturation and function and decreased in vitro anti-mycobacterial activity in the myeloid compartment. Clin Immunol Published Online First: 27 Dec 2015. doi:10.1016/j.clim.2015.12.008

97 Elgizouli M, Lowe DM, Speckmann C, Schubert D, Hulsdunker J, Eskandarian Z, Dudek A, Schmitt-Graeff A, Wanders J, Jorgensen SF, Fevang B, Salzer U, Nieters A, Burns S, Grimbacher B. Activating PI3K $\delta$ mutations in a cohort of 669 patients with primary immunodeficiency. Clin Exp Immunol 2016;183:221-9.

98 Deau MC, Heurtier L, Frange P, Suarez F, Bole-Feysot C, Nitschke P, Cavazzana M, Picard C, Durandy A, Fischer A, Kracker S. A human immunodeficiency caused by mutations in the PIK3R1 gene. J Clin Invest 2014;124:3923-8.

99 Lucas $C L$, Zhang $Y$, Venida A, Wang $Y$, Hughes J, McElwee J, Butrick M, Matthews H, Price S, Biancalana M, Wang X, Richards M, Pozos T, Barlan I, Ozen A, Rao VK, Su HC, Lenardo MJ. Heterozygous splice mutation in PIK3R1 causes human immunodeficiency with lymphoproliferation due to dominant activation of PI3K. J Exp Med 2014;211:2537-47.

100 Parry DA, Maisuria S, Argumugacani G, Logan CV, Wood PM, Cant A, Gooi HC, Johnson CA, Nejentsev S, Doody G, Savic S. Mutation of Phosphoinositide-3-Kinase Regulatory Subunit Alpha 1, Leading to Hyperactivation of Phosphoinositide-3-Kinase, Results in an Immunodeficiency Resembling APDS. J Clin Immunol 2014;34:S179.

101 Kuhlen M, Hönscheid A, Loizou L, Nabhani S, Fischer U, Stepensky P, Schaper J, Klapper W, Siepermann M, Schuster F, Meisel R, Borkhardt A. De novo PIK3R1 gain-of-function with recurrent sinopulmonary infections, long-lasting chronic CMV-lymphadenitis and microcephaly. Clin Immunol 2016;162:27-30.

102 Conley ME, Dobbs AK, Quintana AM, Bosompem A, Wang YD, Coustan-Smith E, Smith AM, Perez EE, Murray PJ. Agammaglobulinemia and absent B lineage cells in a patient lacking the p85 $\alpha$ subunit of PI3K. J Exp Med 2012;209:463-70.

103 Capitani N, Ariani F, Amedei A, Pezzicoli A, Matucci A, Vultaggio A, Troilo A, Renieri A, Baldari CT, D'Elios MM. Vav1 haploinsufficiency in a common variable immunodeficiency patient with defective T-cell function. Int I Immunopathol 2012;25:811-7.

104 Alkhairy OK, Rezaei N, Graham RR, Abolhassani H, Borte S, Hultenby K, Wu C, Aghamohammadi A, Williams DA, Behrens TW, Hammarström L, Pan-Hammarström Q. RAC2 loss-of-function mutation in 2 siblings with characteristics of common variable immunodeficiency. J Allergy Clin Immunol 2015;135:1380-4. e1-5.

105 Compeer EB, Janssen W, van Royen-Kerkhof A, van Gijn M, van Montfrans JM, Boes M. Dysfunctional BLK in common variable immunodeficiency perturbs B-cell proliferation and ability to elicit antigen-specific CD4+ T-cell help. Oncotarget 2015;6:10759-71.

106 Bousfiha A, Jeddane L, Al-Herz W, Ailal F, Casanova JL, Chatila T, Conley ME, Cunningham-Rundles C, Etzioni A, Franco JL, Gaspar HB, Holland SM, Klein C, Nonoyama S, Ochs HD, Oksenhendler E, Picard C, Puck JM, Sullivan KE, Tang ML. The 2015 IUIS Phenotypic Classification for Primary Immunodeficiencies. J Allergy Clin Immunol 2015;35:727-38.

107 Chou J, Lutskiy M, Tsitsikov E, Notarangelo LD, Geha RS, Dioun A. Presence of hypogammaglobulinemia and abnormal antibody responses in GATA2 deficiency. J Allergy Clin Immunol 2014;134:223-6. 
108 Buchbinder D, Baker R, Lee YN, Ravell J, Zhang Y, McElwee J, Nugent D, Coonrod EM, Durtschi JD, Augustine NH, Voelkerding KV, Csomos K, Rosen L, Browne S, Walter JE, Notarangelo LD, Hill HR, Kumánovics A. Identification of patients with RAG mutations previously diagnosed with common variable immunodeficiency disorders. J Clin Immunol 2015;35:119-24.

109 Abolhassani H, Wang N, Aghamohammadi A, Rezaei N, Lee YN, Frugoni F, Notarangelo LD, Pan-Hammarström Q, Hammarström L. A hypomorphic recombination-activating gene 1 (RAG1) mutation resulting in a phenotype resembling common variable immunodeficiency. J Allergy Clin Immunol 2014;134:1375-80.

110 Abolhassani H, Cheraghi T, Rezaei N, Aghamohammadi A, Hammarstrom L. Common variable immunodeficiency or late-onset combined immunodeficiency: a new hypomorphic JAK3 patient and review of the literature. J Investig Allergol Clin Immunol 2015:25:218-20.

111 Volk T, Pannicke U, Reisli I, Bulashevska A, Ritter J, Björkman A, Schäffer AA, Fliegauf M, Sayar EH, Salzer U, Fisch P, Pfeifer D, Di Virgilio M, Cao H, Yang F, Zimmermann K, Keles S, Caliskaner Z, Güner SÜ, Schindler D, Hammarström L, Rizzi M, Hummel M, Pan-Hammarström Q, Schwarz K, Grimbacher B. DCLRE1C (ARTEMIS) mutations causing phenotypes ranging from atypical severe combined immunodeficiency to mere antibody deficiency. Hum Mol Genet 2015:24:7361-72.

112 De Leeneer K, Hellemans J, Steyaert W, Lefever S, Vereecke I, Debals E, Crombez B, Baetens M, Van Heetvelde M, Coppieters F, Vandesompele J, De Jaegher A, De Baere E, Coucke P, Claes K. Flexible, scalable, and efficient targeted resequencing on a benchtop sequencer for variant detection in clinical practice. Hum Mutat 2015:36:379-87.

113 Yang Y, Muzny DM, Reid JG, Bainbridge MN, Willis A, Ward PA, Braxton A, Beuten J, Xia F, Niu Z, Hardison M, Person R, Bekheirnia MR, Leduc MS, Kirby A, Pham P, Scull J, Wang M, Ding Y, Plon SE, Lupski JR, Beaudet AL, Gibbs RA, Eng CM. Clinical whole-exome sequencing for the diagnosis of mendelian disorders. N Engl J Med 2013;369:1502-11.

114 Meienberg J, Bruggmann R, Oexle K, Matyas G. Clinical sequencing: is WGS the better WES? Hum Genet 2016;135:359-62.

115 Di Pierro V, Zuntini R, Cancrini C, Finocchi A, Angelino G, Rossi P, Ferrari S. Consanguinity and polygenic diseases: a model for antibody deficiencies. Hum Hered 2014;77:144-9.

116 Orange JS, Glessner JT, Resnick E, Sullivan KE, Lucas M, Ferry B, Kim CE, Hou C, Wang F, Chiavacci R, Kugathasan S, Sleasman JW, Baldassano R, Perez EE, Chapel $\mathrm{H}$, Cunningham-Rundles $\mathrm{C}$, Hakonarson $\mathrm{H}$. Genome-wide association identifies diverse causes of common variable immunodeficiency. J Allergy Clin Immunol 2011;127:1360-7.e6.

117 Rodríguez-Cortez VC, Del Pino-Molina L, Rodríguez-Ubreva J, Ciudad L, Gómez-Cabrero D, Company C, Urquiza JM, Tegnér J, Rodríguez-Gallego C, López-Granados E, Ballestar E. Monozygotic twins discordant for common variable immunodeficiency reveal impaired DNA demethylation during naive-to-memory B-cell transition. Nat Commun 2015;6:7335.

118 Offer SM, Pan-Hammarström Q, Hammarström L, Harris RS. Unique DNA repair gene variations and potential associations with the primary antibody deficiency syndromes IgAD and CVID. PLOS ONE 2010;5:e12260.

119 Flinsenberg TW, Janssen WJ, Herczenik E, Boross P, Nederend M, Jongeneel LH, Scholman RC, Boelens JJ, Maas C, van Gijn ME, van Montfrans JM, Leusen JH, Boes M. A novel Fc $\gamma$ RIla Q27W gene variant is associated with common variable immune deficiency through defective FcyRlla downstream signaling. Clin Immunol 2014;155:108-17.

120 Packwood K, Drewe E, Staples E, Webster D, Witte T, Litzman J, Egner W, Sargur R, Sewell W, Lopez-Granados E, Seneviratne SL, Powell RJ, Ferry BL, Chapel HM. NOD2 polymorphisms in clinical phenotypes of common variable immunodeficiency disorders. Clin Exp Immunol 2010;161:536-41.

121 Bellacchio E, Palma A, Corrente S, Di Girolamo F, Helen Kemp E, Di Matteo G, Comelli L, Carsetti R, Cascioli S, Cancrini C, Fierabracci A. The possible implication of the $S 250$ C variant of the autoimmune regulator protein in a patient with autoimmunity and immunodeficiency: in silico analysis suggests a molecular pathogenic mechanism for the variant. Gene 2014;549:286-94.

122 Borte S, Celiksoy MH, Menzel V, Ozkaya O, Ozen FZ, Hammarström L, Yildiran A. Novel NLRP12 mutations associated with intestinal amyloidosis in a patient diagnosed with common variable immunodeficiency. Clin Immunol 2014;154:105-11.

123 Vorechovský I, Cullen M, Carrington M, Hammarström L, Webster AD. Fine mapping of IGAD1 in IgA deficiency and common variable immunodeficiency: identification and characterization of haplotypes shared by affected members of 101 multiple-case families. J Immunol 2000;164:4408-16.

124 Liao M, Ye F, Zhang B, Huang L, Xiao Q, Qin M, Mo L, Tan A, Gao Y, Lu Z, Wu C, Zhang Y, Zhang H, Qin X, Hu Y, Yang X, Mo Z. Genome-wide association study identifies common variants at TNFRSF13B associated with IgG level in a healthy Chinese Male population. Genes Immun 2012;13: 509-13. 